\title{
An Optimized and Well-Characterized Niosome- Based Nanocarrier for Letrozole: A Brand- New Hybrid Therapy for Breast Cancer
}

\section{Saeedeh Ahmadi}

Pasteur Institute of Iran

Iman Akbarzadeh

Pasteur Institute of Iran

Mohsen Chiani ( $\square$ chiani@pasteur.ac.ir)

Pasteur Institute of Iran

\section{Mahmoud Seraj}

Aja University of Medical Sciences

\section{Hassan Noorbazargan}

Shahid Beheshti University

\section{Samaneh Saffar}

Pasteur Institute of Iran

\section{Sameer Quazi}

GenLab BioSolutions Private Limited

\section{Bahareh Farasati Far}

Iran University of Science and Technology

\section{Research Article}

Keywords: Drug delivery system, Niosome, Letrozole, Breast cancer, Anticancer.

Posted Date: December 30th, 2021

DOI: https://doi.org/10.21203/rs.3.rs-1197164/v1

License: (1) (1) This work is licensed under a Creative Commons Attribution 4.0 International License. Read Full License 


\section{An optimized and well-characterized niosome-based nanocarrier for letrozole: a brand- new hybrid therapy for breast cancer}

Saeedeh Ahmadi ${ }^{\mathrm{a}, \mathrm{b}}$, Iman Akbarzadeh ${ }^{\mathrm{a}, \mathrm{c}}$, Mohsen Chiani ${ }^{\mathrm{a},{ }^{*}, \text { Mahmoud Seraj }}{ }^{\mathrm{d}, \text { * }}$, Hassan

Noorbazargan $^{\mathrm{e}}$, Samaneh Saffar ${ }^{\mathrm{f}}$, Sameer Quazi ${ }^{\mathrm{g}}$, Bahareh Farasati Far ${ }^{\mathrm{h}}$

a Department of Nano Biotechnology, New Technology Research Group, Pasteur Institute of Iran, Tehran, Iran.

${ }^{\mathrm{b}}$ Department of Biology, Science and Research Branch, Islamic Azad University, Tehran, Iran.

${ }^{c}$ Department of Chemical and Petrochemical Engineering, Sharif University of Technology, Tehran, Iran.

${ }^{\mathrm{d}}$ Department of Clinical Biochemistry, Integrative Research Laboratory, Aja University of Medical Sciences, Tehran, Iran.

${ }^{\mathrm{e}}$ Department of Biotechnology, School of Advanced Technologies in Medicine, Shahid Beheshti University of Medical.

${ }^{\mathrm{f}}$ Core Facility Lab, Pasteur Institute of Iran, Tehran, Iran.

g GenLab BioSolutions Private Limited, Bangalore, Karnataka, India.

${ }^{\mathrm{h}}$ Department of Chemistry, Iran University of Science and Technology, Tehran, Iran.

*Corresponding authors:

Mohsen Chiani, Department of Nano Biotechnology, New Technology Research Group, Pasteur Institute of Iran, Tehran, Iran. E-mail: chiani@pasteur.ac.ir Mahmoud Seraj, Department of Clinical Biochemistry, Integrative Research Laboratory, Aja University of Medical Sciences, Tehran, Iran. E-mail: mscseraj@gmail.com Sameer Quazi, GenLab Biosolutions Private Limited, Bangalore, Karnataka, India. 


\begin{abstract}
This study aimed to improve the anticancer activity of letrozole through a niosomal formulation. Optimized niosomal formulation of letrozole was achieved by response surface methodology (RSM). The niosomes were well-characterized by several methods. The anticancer activity and its mechanism were studied in MCF-7 and MDA-MB-231 breast cancer cells. The release of the drug from the niosomes was according to the Kors MeyerPeppa kinetic model. The niosomes were stable with high encapsulation efficiency. Significant higher anticancer activity and more induction of apoptosis were obtained for niosomal letrozole. Results indicated that niosomes could be a promising drug carrier for delivery of letrozole to breast cancer cells.
\end{abstract}

Keywords: Drug delivery system; Niosome; Letrozole; Breast cancer; Anticancer. 


\section{Introduction}

According to WHO report, cancer is the second leading cause of death in the world, and is responsible for an estimated 9.6 million deaths in $2018^{[1]}$. Breast cancer is the most common malignancy among women according to 246,660 new cases of breast cancer and $14 \%$ of reported deaths due to breast cancer in the United States in $2016^{[2]}$. The aromatase-dependent breast cancer type is treated with letrozole as a hormonal anticancer. Aromatase is a biocatalyst enzyme that increases the biosynthesis of estrogen from testosterone ${ }^{[3]}$. However, letrozole decreases estrogen level by blocking cytochrome P-450 that converts testosterone into small amounts of estrogen in postmenopausal women; it does not stop estrogen production in the ovaries. By decreasing the amount of estrogen, the growth of hormonereceptor-positive breast cancer cells is decreased ${ }^{[4]}$. Recently, targeted drug delivery systems received extensive attention ${ }^{[5,6]}$. The combination of medicine and nanotechnology has modified multifunctional nanocarriers that can be loaded with different drugs ${ }^{[1,2,7,8]}$. Niosomes as nonionic surfactants have been widely studied due to their useful properties including biodegradability, biocompatibility, low immunogenicity, long shelf life, high stability, and allow drug delivery to the target site at a controlled release rate ${ }^{[4,9-12]}$. Researchers demonstrated that aqueous solubility and oral bioavailability of niosomal Candesartan cilexetil- a commercially marketed compound with low bioavailability (15\%) significantly enhanced $^{[13]}$. In another study, PEGylated niosomal vincristine showed potent in vitro toxicity in BCL1 lymphoma cancer cells ${ }^{[14]}$. A PEGylated niosomal formulation of artemisinin was prepared by Asgharkhani and his colleagues. The anticancer activity of the new formulation was evaluated against MCF-7 breast cancer cells. They found a significant cytotoxicity effect for niosomal artemisinin compared to the free drug solution ${ }^{[15]}$. In this paper, the attempts are made to indicate the efficacy of niosomal letrozole on breast tumor cells. In this regard, letrozole-loaded niosomes was optimized, formulated, and 
physiochemically characterized by several techniques. The mean particle size, zeta potential, drug entrapment efficacy, in vitro drug release, and stability of the niosomes were determined. Furthermore, the cytotoxic effects of letrozole-loaded niosomes against MCF7, MDA-MB, and MCF10A cell lines were evaluated. Real-time, flow cytometry and cell cycle analysis were used to determine the expression rate of apoptosis-related genes (P53, BCL2, and Bax).

\section{Materials and methods}

\subsection{Materials}

Letrozole was kindly donated by Tofigh Daru (Tehran, Iran). Sorbitan monolaurate (Span20, Cat\# S6635), Sorbitan monostearate (Span60, Cat\# S7710), Sorbitan monooleate (Span80, Cat\# S6760), Cholesterol (CHOL, Cat\# C8667), dicetylphosphate (DCP, Cat\# 850042P), Sodium dodecyl sulfate (SDS, Cat\# L3771) and dialysis membrane (MWCO 12kDa, Cat\# D6191) were obtained from Sigma Aldrich (USA). Dimethyl sulfoxide (DMSO, Cat\# 109678), Chloroform (Cat\# 107024), Amicon (Ultra-15-Membrane, MWCO 30kDa, Cat\# C82301) were purchased from Merck (Germany). Trypsin-EDTA (Cat\# 15400054), Trypan blue (Cat\# 15250061), RPMI-1640 culture medium, DMEM (Dulbecco's Modified Eagle culture medium, Cat\# 11965092), phosphate-buffered saline (PBS, Cat\# 10010049), fetal bovine serum (FBS, Cat\# 16000044), MTT (3-(4,5-Dimethylthiazol-2-yl)-2,5 Diphenyltetrazolium Bromide) (Cat\# M6494) and penicillin /streptomycin (PS, Cat\# 10378016)100 X were purchased from Gibco, (USA). The MDA-MB-231, MCF-7, and MCF10A cell lines were obtained from Pasteur Cell Bank (Iran). The Annexin V-FITC flow cytometric kit was obtained from Affymetrix biosciences (USA). RNA extraction and cDNA synthesis kits were purchased from Transgene Biotech, China (Cat\#. ER101-01 and AE30102). 


\subsection{Preparation of letrozole-loaded niosomes}

Letrozole-loaded niosomes were formulated by the thin-film hydration method ${ }^{[7,16]}$. The lipid: drug mixture was prepared in different molar ratios of 10: 1 and 20: 1. Surfactant (either Span20, 60 or 80): CHOL: DCP (as a negative charge inducing agent) ratio was kept 2:1:0.05 in all batches. The mixture was dissolved in $10 \mathrm{~mL}$ chloroform. The organic phase was evaporated under reduced pressure using a rotary evaporator (Heidolph, Germany) at 60 ${ }^{\circ} \mathrm{C}$ for $30 \mathrm{~min}$. The dried film was hydrated in $10 \mathrm{ml}$ of PBS for $30 \mathrm{~min}$ at $60{ }^{\circ} \mathrm{C}$ and rotation at $120 \mathrm{rpm}$. Finally, the solution was sonicated for $5 \mathrm{~min}$ by Hielscher up to $50 \mathrm{H}$ ultrasonic processor, Germany. Different niosomal formulations of letrozole are presented in Table 1.

Table 1. Different niosomal formulations for encapsulation of letrozole

\begin{tabular}{|c|c|c|c|c|c|c|c|}
\hline $\begin{array}{l}\text { Formula } \\
\text { tion }\end{array}$ & $\begin{array}{l}\text { Type of } \\
\text { Surfact } \\
\text { ant }\end{array}$ & $\begin{array}{l}\text { Lipida/D } \\
\text { rug } \\
\text { (mol } \\
\text { ratio) }\end{array}$ & $\begin{array}{l}\text { HL } \\
\text { B }\end{array}$ & $\begin{array}{l}\text { Transitio } \\
\text { n } \\
\text { temperat } \\
\text { ure, Tc } \\
\left({ }^{\circ} \mathrm{C}\right)\end{array}$ & $\begin{array}{l}\text { Drug } \\
\text { concentration( } \\
\mathrm{mg} / \mathrm{ml})\end{array}$ & $\begin{array}{l}\text { Sonicat } \\
\text { ion } \\
\text { time } \\
\text { (min) }\end{array}$ & $\begin{array}{l}\text { Surfacta } \\
\text { nt: } \\
\text { Choleste } \\
\text { rol: } \\
\text { DCP } \\
\text { (molar } \\
\text { ratio) }\end{array}$ \\
\hline $\mathrm{L}_{1}$ & Span20 & 10 & $\begin{array}{l}8.6 \\
0\end{array}$ & 16 & 1 & 5 & $2: 1: 0.05$ \\
\hline $\mathrm{L}_{2}$ & Span60 & 10 & $\begin{array}{l}4.7 \\
0\end{array}$ & 53 & 1 & 5 & $2: 1: 0.05$ \\
\hline $\mathrm{L}_{3}$ & Span80 & 10 & $\begin{array}{l}4.3 \\
0\end{array}$ & -12 & 1 & 5 & $2: 1: 0.05$ \\
\hline $\mathrm{L}_{4}$ & Span20 & 20 & $\begin{array}{l}8.6 \\
0\end{array}$ & 16 & 1 & 5 & $2: 1: 0.05$ \\
\hline $\mathrm{L}_{5}$ & Span60 & 20 & $\begin{array}{l}4.7 \\
0\end{array}$ & 53 & 1 & 5 & $2: 1: 0.05$ \\
\hline
\end{tabular}




\begin{tabular}{llllllll}
\hline $\mathrm{L}_{6}$ & Span80 & 20 & 4.3 & -12 & 1 & 5 & $2: 1: 0.05$
\end{tabular}

a Lipid is the total amount of cholesterol and surfactant and DCP

b DCP: Dicetyl phosphate

\subsection{Particle Size, Size Distribution, and Zeta Potential}

The mean particle size and the polydispersity index of the niosomes were determined by the Zeta-sizer instrument at a wavelength of $25^{\circ} \mathrm{C}$ and $633 \mathrm{~nm}$ (Nano ZS3600, Malvern Instruments Ltd, UK) which based on dynamic light scattering.

\subsection{Morphology}

The surface morphology of the optimized formulation was visualized by SEM (scanning electron microscopy), TEM (transmission electron microscopy), and AFM (Atomic force microscopy). For SEM, the letrozole loaded niosomes suspension was diluted with deionized water and a drop of that was placed on a silicon wafer and dried completely overnight in a desiccator. Then a thin gold layer was sputtered on the samples, and they were studied under a field emission scanning electron microscope (NOVA NANOSEM 450 FEI, USA). TEM analysis was performed by placing a drop of letrozole loaded niosomes on carbon-coated300-mesh copper grids, the excess sample was removed after 2 min by a filter paper. Samples were eluted by distilled water and stained by $2 \%$ Uranyl acetate. Final analysis was performed at $80 \mathrm{kV}$ on a field emission TEM (TENAI G2 F20, USA). AFM samples were prepared by placing $5 \mu 1$ of diluted niosomes on $1 \mathrm{~cm}^{2}$ glass slides and left to dry at room temperature. Prepared samples were visualized with a Nanowizard II atomic force microscope (JPK Instruments, Berlin, Germany) with a low-stress silicon nitride cantilevers (AppNano, USA) using AC mode at $66 \mathrm{k} \mathrm{Hz} \mathrm{scan}{ }^{[17,18]}$. 


\subsection{Fourier-transform infrared spectroscopy (FT-IR)}

To study the interaction between different ingredients, we performed Fourier transform infrared (FTIR) spectroscopy by enjoying Spectrum Two, PerkinElmer, USA, and KBr disc method. Samples were scanned over the range of 4000 to $400 \mathrm{~cm}^{-1}$. Infrared spectroscopic studies were done for letrozole, Span80, Cholesterol, DCP, letrozole loaded niosomes and drug-free niosome (niosomes without drug or empty niosomes). Sample's scanning was carefully conducted by using the PerkinElmer Spectrum software (Model 1600, Massachusetts, US).

\subsection{Differential scanning calorimetry (DSC) measurements}

Pure letrozole, letrozole loaded niosomes, and drug-free niosomes samples were also analyzed by differential scanning calorimetric method (TA, Q600, USA). To do this, $3 \mathrm{mg}$ of each sample was sealed thematically in aluminum pans (scan range temperature was from 20 to $300^{\circ} \mathrm{C}$ with $5^{\circ} \mathrm{C} /$ min scan rate). The study was operated under nitrogen as the purge gas.

\subsection{Powder X-ray diffractometry (XRD) analysis}

X-ray diffraction (XRD) studies was performed by X' Pert Pro MPD, Panalytical, Netherlands. In this regard, letrozole loaded niosomes, dug-free niosomes and letrozole were taken into plane glasses. Small-angle XRD was acquired using an X-ray super-speed diffractometer with a $\mathrm{Ni}$ filter and $\mathrm{Cu}$ radiation $(\lambda=0.542 \mathrm{~nm})$, tube voltage $25-45 \mathrm{kV}$ and tube current $100-200 \mathrm{~mA}$, and scanned from $2^{\circ}$ to $80^{\circ}, 2 \theta$.

\subsection{Entrapment efficiency (EE \%)}

Entrapment efficiency was calculated by measuring concentration of non-entrapped letrozole. In this regard, the free drug was separated from niosomal dispersion by Ultracel-30K 
Millipore filters with a molecular weight cut-off (MWCO) of 30,000 Da. The inner chamber of the cell was filled by $500 \mu \mathrm{l}$ of formulations and the assembly was centrifuged for $20 \mathrm{~min}$ at $4000 \times \mathrm{g}$ in $4^{\circ} \mathrm{C}$ by cooling centrifuge (Eppendorf ${ }^{\circledR} 580 \mathrm{R}$ centrifuge, Germany). The amount of free drug in the outer chamber of the device was determined by UV-visible spectrophotometry at $240 \mathrm{~nm}$ (JASCO, V-530, Japan). The encapsulation efficiency was calculated by the following equation.

$$
E E(\%)=\frac{\text { Initial drug added }- \text { Free drug }}{\text { Initial drug added }} \times 100
$$

\subsection{In vitro release study and kinetic model}

The in vitro release of drugs from letrozole-loaded niosomes was studied using the dialysis diffusion method (molecular weight $12 \mathrm{KDa}$ ). To do this, two milliliters of the niosomal suspension were placed into dialysis bag, sealed, and immersed into $50 \mathrm{ml}$ of PBS (pH 6.8, $37^{\circ} \mathrm{C}$ ) as release or receiver medium and shacked on a magnetic stirrer at 300rpm. Samples were taken from the buffer compartment at predetermined time intervals and replaced by fresh PBS. The optical density of each batch was determined by UV-Vis spectrophotometer at wavelength of $240 \mathrm{~nm}$ and the amount of released drug was estimated by standard curve equation. The cumulative release was then plotted against the time. The kinetic of release was analyzed by the Higuchi, Korsmeyer-Peppas, zero-order and first-order models.

\subsection{Stability studies}

The stability of optimized letrozole loaded niosomes was studied for 60 days at two different temperatures $\left(25 \pm 2^{\circ} \mathrm{C}\right.$ and $\left.4 \pm 2^{\circ} \mathrm{C}\right)$. At specific time intervals (14, 30 and 60 days) the particle 
size (Z-average), polydispersity index (PDI) and entrapment efficiency (EE) of the dispersions were measured and the results compared to fresh samples.

\subsection{Cytotoxicity assay}

MCF-7, MDA-MB-231 and MCF10A cells were cultured separately at a density of $1 \times 10^{4}$ cells per well in 96-well tissue culture plates and incubated at $37{ }^{\circ} \mathrm{C}$ in $5 \% \mathrm{CO}_{2}$ incubator for 24 hours. Different concentrations $(0-200 \mu \mathrm{g} / \mathrm{ml})$ of drug-free niosome $\left(\mathrm{L}_{3 \mathrm{~B}}\right)$, letrozole solution $(\mathrm{L})$, letrozole loaded niosomes $\left(\mathrm{L}_{3}\right)$ and letrozole mixed by letrozole loaded niosome $\left(\mathrm{L}+\mathrm{L}_{3} ; 1: 2 \mathrm{v} / \mathrm{v}\right)$ were added to 96 well plates in eight replicates and incubated at $37^{\circ} \mathrm{C}$ in a $5 \% \mathrm{CO}_{2}$ incubator for 48 and 72 hours. After incubation, cells were treated by $100 \mu \mathrm{L}$ of MTT $(0.5 \mathrm{mg} / \mathrm{ml}$ in PBS $)$ and incubated for 4 hours in a $5 \% \mathrm{CO}_{2}$ incubator at $37^{\circ} \mathrm{C}$. Then $100 \mu \mathrm{L}$ of DMSO was added to each well after removing the medium. Formazan formation was quantified using a microplate reader (Biotek, USA). Finally, the cell viability for each treatment was calculated by the following equation:

Cell viability $(\%)=($ A treatment $\mathrm{A}$ blank $) /(\mathrm{A}$ control A blank $) \times 100 \quad($ Equation 2$)$

\subsection{Apoptotic gene expression analysis}

MCF-7, MDA-MB-231 and also MCF10A cells were treated with $\mathrm{L}_{3 \mathrm{~B}}$, L, L3, and L + L3 (1:2 $\mathrm{v} / \mathrm{v}$ ) at $\mathrm{IC}_{50}$ concentrations for $72 \mathrm{~h}$. The RNA extraction kit (Transgene biotech) was used for isolation of RNA content of the treated cells. The cDNAs were obtained using the cDNA synthesis kit (Takara, Japan). The expression rate of $B C L_{2}, B a x$, and $P 53$ were assessed using real time PCR. The beta actin ( $\beta$-actin) expression level was used as an internal control. The real time PCR primers were listed in Table 2. The real-time PCR program was as follows: 95 ${ }^{\circ} \mathrm{C} 10 \mathrm{~min}, 95^{\circ} \mathrm{C} 15 \mathrm{sec} .(35 \mathrm{cycles})$, and $72^{\circ} \mathrm{C} 1 \mathrm{~min}$. The total volume of the amplification reaction was $20 \mu \mathrm{L}$ using SYBR® Green Master Mix (Bio-Rad, USA) and the products were 
run on $2 \%$ agarose gel. Data were evaluated by the icycler iQ real-time detection system, and the fold changes were calculated based on the threshold cycle $\left(C_{t}\right)$ value.

Table 2. Primers and their sequences used in the real time PCR ${ }^{[4]}$.

\begin{tabular}{|c|c|c|}
\hline Gene & Forward Primer & Reverse Primer \\
\hline Bax & 5'-CGGCAACTTCAACTGGGG-3' & 5'-TCCAGCCCAACAGCCG-3' \\
\hline$B C L_{2}$ & 5-'GGTGCCGGTTCAGGTACTCA-3' & $\begin{array}{l}\text { 5'-TTGTGGCCTTCTTTGAGTTCG- } \\
3 \text {, }\end{array}$ \\
\hline P53 & $\begin{array}{l}5^{\prime}- \\
\text { CATCTACAAGCAGTCACAGCACAT- } \\
3,\end{array}$ & $\begin{array}{l}\text { 5'-CAACCTCAGGCGGCTCATAG- } \\
3 \text { ' }\end{array}$ \\
\hline $\begin{array}{l}\beta- \\
\beta- \\
\operatorname{actin}\end{array}$ & 5-'TCCTCCTGAGCGCAAGTAC -3' & $\begin{array}{l}\text { 5'CCTGCTTGCTGATCCACATCT- } \\
3 \text {, }\end{array}$ \\
\hline
\end{tabular}

\subsection{Flow cytometry}

MCF-7, MDA-MB-231 and MCF10A cells were seeded in cell culture plate at a density of $5 \times 10^{5}$ cell/well and incubated overnight at $37^{\circ} \mathrm{C}$ in a $5 \% \mathrm{CO}_{2}$ to attach completely. Then, the cells were separately treated with $\mathrm{L}_{3 \mathrm{~B}}, \mathrm{~L}, \mathrm{~L}_{3}$ and $\mathrm{L}_{+} \mathrm{L}_{3}(1: 2 \mathrm{v} / \mathrm{v})$ at $\mathrm{IC}_{50}$ concentrations for 72 h. After washing twice with cold sterile PBS ( $\mathrm{pH} 7.4$ ), $1 \times 10^{6}$ cells were suspended in 250 $\mu \mathrm{L}$ binding buffer provided by the kit (Transgene Biotech ER101-01). According to manufacturer's instruction, certain amounts of propidium iodide and annexin v added to the cells and incubated for $10 \mathrm{~min}$ at room temperature. In the final step, the cell suspensions were moved to a flow cytometric tube and subjected to flow cytometry analysis (BD Biosciences, Singapore).

\subsection{Cell cycle analysis}


Propidium iodide (PI) staining was used to evaluate cell proliferation. In this regard, DNA content is used to detect the cell cycle stage, so the binding of PI to DNA is proportional to the DNA content. Cells were seeded in complete medium in 6-well plates at a density of $1 \times$ $10^{6}$ cells/well. After an overnight incubation and three times washing with PBS, cells were treated with $\mathrm{L}, \mathrm{L}_{3}, \mathrm{~L}+\mathrm{L}_{3}(1: 2 \mathrm{v} / \mathrm{v})$ for $72 \mathrm{~h}$ in complete medium. After that, cells were collected and fixed with $70 \%$ cold ethanol overnight at $4{ }^{\circ} \mathrm{C}$, and stained with $500 \mu \mathrm{l}$ of PI solution (containing RNase) in the dark for $20 \mathrm{~min}$ at room temperature and then analyzed by flow cytometry. Experiments were repeated three times.

\section{Results}

\subsection{Niosomal letrozole formulations}

Table 3 represents the impact of the type of surfactant and the molar ratio of lipid to drug on the structure and physicochemical properties of the prepared niosome. Results indicated that the niosomal formulations with different lipid/drug molar ratio and various surfactant types were indicated varied size and polydispersity index. Among different employed surfactants, the Span 80 with both lipids to drug molar ratio (10 and 20) formulation had optimal characterization parameters. However, among formulations with Span 20 and 60 those which were prepared based on 10 molar ratios of lipid to drug had smaller size and higher entrapment efficacy in contrast with formulation which was prepared based on 20 molar ratios of lipid to drug. Consequently, formulations obtained from span20, span60 and span80 in a lipid-to-drug molar ratio of 10 were selected for further analyses.

Table 3. Vesicle size, PDI, and EE \% of different niosomal formulations. Data are represented as mean $\pm \mathrm{SD}, \mathrm{n}=3$.

\begin{tabular}{llll}
\hline Formulation & $\begin{array}{l}\text { Vesicle Size }(\mathbf{n m}, \\
\text { average } \pm \text { SD) }\end{array}$ & $\begin{array}{l}\text { Polydispersity index } \\
(\text { average } \pm \text { SD) }\end{array}$ & $\begin{array}{l}\text { EE (\%) (average } \pm \\
\text { SD) }\end{array}$ \\
\hline $\mathrm{L}_{1}$ & $242.90 \pm 9.90$ & $0.127 \pm 0.023$ & $94.4158 \pm 0.0534$
\end{tabular}




\begin{tabular}{llll}
\hline $\mathrm{L}_{2}$ & $186.70 \pm 2.88$ & $0.181 \pm 0.012$ & $96.0620 \pm 0.0051$ \\
\hline $\mathrm{L}_{3}$ & $190.30 \pm 17.84$ & $0.162 \pm 0.007$ & $97.9974 \pm 0.0175$ \\
\hline $\mathrm{L}_{4}$ & $301.73 \pm 19.23$ & $0.213 \pm 0.035$ & $91.3281 \pm 0.0304$ \\
\hline $\mathrm{L}_{5}$ & $184.33 \pm 7.35$ & $0.234 \pm 0.014$ & $94.5825 \pm 0.1674$ \\
\hline $\mathrm{L}_{6}$ & $176.03 \pm 7.25$ & $0.283 \pm 0.058$ & $98.4772 \pm 0.2063$
\end{tabular}

\subsection{Morphological Characterization of Optimized Niosomes}

Morphology of the optimized niosomal formulation $\left(\mathrm{L}_{3}\right)$ was studied by SEM, TEM and AFM. Figure 1a shows the SEM image of the niosomes, which confirms a uniform spherical shape and a smooth surface with an average size of $40 \mathrm{~nm}$ without any aggregation. The size of the niosomes obtained by SEM was smaller than that measured by the Nano Zetasizer.

Figure 1b illustrates internal and topology structure of the niosomes which have been imaged by TEM. This image also confirmed the spherical and uniform structure of the vesicles. The AFM image of the niosomes is indicated in Figure 1c. In this figure, the niosomes also showed a spherical shape, but there was a large variation in the vesicle size, which may be related to the fusion of the niosomes as a result of interactions between the mica substrate and niosome surfaces. There was no significant difference between the sizes of the niosomes in all different methods. 


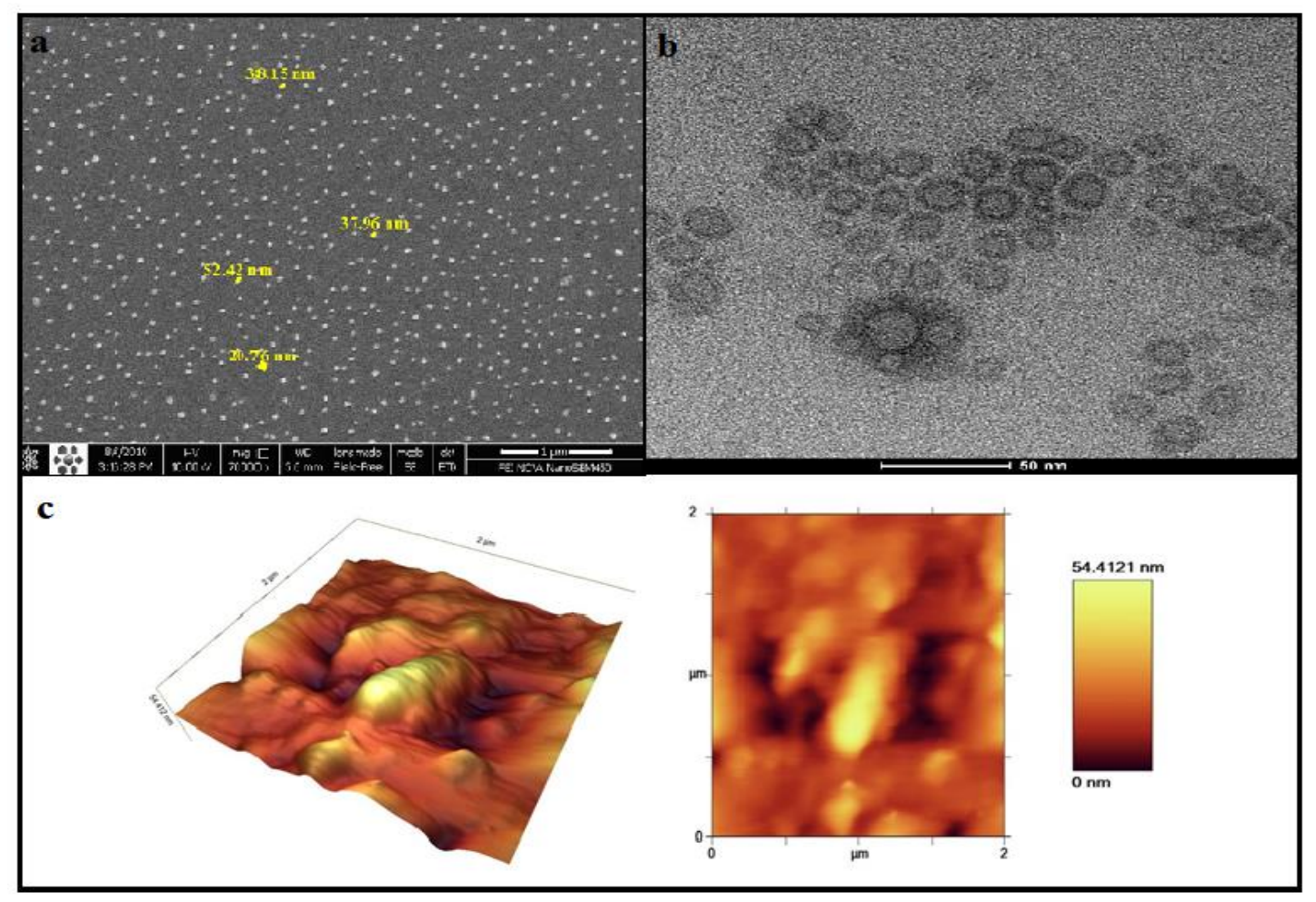

Figure 1. Morphological characterization of optimized niosomes: (a) scanning electron microscopy (SEM), (b) transmission electron microscopy (TEM) and (c) Atomic force microscopy (AFM).

\subsection{Fourier transform infrared (FT-IR) analysis}

FT-IR spectra for different components of the niosomal formulations are represented in

Table 4. The optimized drug-free niosomes (control) have most of the characteristic peaks of its components, including 80, DCP and cholesterol (see Figure 2, Table 4) ${ }^{[19]}$. FT-IR spectrum of letrozole showed intense band of functional groups, $1640-1690 \mathrm{~cm}^{-1}(\mathrm{~N}=\mathrm{C}$ bonding), $800 \mathrm{~cm}^{-1}$ (N-H out-of-plane bending vibrations), $1550-1640 \mathrm{~cm}^{-1}$ (N-H bonding), $1600-1680 \mathrm{~cm}^{-1}$ (C-C bonding), $1450-1600 \mathrm{~cm}^{-1}$ (Aromatic ring of $\mathrm{C}=\mathrm{C}$ ), $2250 \mathrm{~cm}^{-1}(\mathrm{C} \equiv \mathrm{N}$ bonding), and 1000-1350 $\mathrm{cm}^{-1}$ (N-C bonding). The IR spectrum of letrozole loaded niosome showed characteristics peaks at $3452 \mathrm{~cm}^{-1}$, (O-H stretching), $1125 \mathrm{~cm}^{-1}(\mathrm{C}-\mathrm{O}$ stretching), $1747 \mathrm{~cm}^{-1}$ (C =O stretching), 1000-1250 $\mathrm{cm}^{-1}$ (Aliphatic C-N stretching), and 2800-3000 $\mathrm{cm}^{-1}$ (C-H stretching). Furthermore, the FT-IR spectrum of excipients including Span80, 
cholesterol, and DCP has been reported in Table 4. However, the $\mathrm{C}=\mathrm{C}$ stretching peaks (at $1674 \mathrm{~cm}^{-1}$ ) peaks in cholesterol have vanished in the FT-IR spectra of the niosomes, further demonstrating the entrapment of cholesterol in the lipid bilayer shell and the formation of the niosomes ${ }^{[20,21]}$. Another important result was disappearing of the main characteristics peaks of the drug molecule in the final optimized niosomal formulation, which revealed the successful encapsulation of the drug by the niosomes.

Table 4. The main characteristic peaks for FT-IR spectra of different samples or chemicals.

\begin{tabular}{|c|c|c|}
\hline Sample, chemicals & Peak cm-1 & Description \\
\hline \multirow{4}{*}{ DCP } & 1243 & $\mathrm{P}=\mathrm{O}$ bonding \\
\hline & $724-843$ & P-O bonding \\
\hline & 1450 & $\mathrm{CH} 3$ bonding \\
\hline & 1465 & $\mathrm{CH} 2$ bonding \\
\hline \multirow{6}{*}{ Span 80} & $1000-1300$ & $\mathrm{C}-\mathrm{O}$ stretching \\
\hline & $2800-3000$ & C-H stretching \\
\hline & 3452 & OH stretching \\
\hline & 1749 & $\mathrm{CH} 2$ bonding \\
\hline & 1753 & $\mathrm{C}=\mathrm{O}$ stretching \\
\hline & 1497 & Aromatic ring \\
\hline \multirow{6}{*}{ Cholesterol } & 1747 & $\mathrm{C}=\mathrm{O}$ stretching \\
\hline & $2800-3000$ & C-H stretching \\
\hline & 3452 & OH stretching \\
\hline & $1035-1378$ & $\mathrm{CH} 2$ bending and $\mathrm{CH} 2$ deformation \\
\hline & 1506 & $\mathrm{C}-\mathrm{C}$ stretching in aromatic ring \\
\hline & 1674 & $\mathrm{C}=\mathrm{C}$ stretching \\
\hline \multirow{6}{*}{ Niosome } & 1165 & $\mathrm{C}-\mathrm{O}$ stretching \\
\hline & 1745 & $\mathrm{C}=\mathrm{O}$ stretching \\
\hline & $2800-3000$ & C-H stretching \\
\hline & 1498 & Aromatic ring \\
\hline & $1000-1250$ & Aliphatic C-N stretching \\
\hline & 3452 & OH stretching \\
\hline \multirow{7}{*}{ Letrozole } & $1640-1690$ & $\mathrm{~N}=\mathrm{C}$ bonding \\
\hline & 800 & $\mathrm{~N}-\mathrm{H}$ out-of-plane bending vibrations \\
\hline & $1450-1600$ & Aromatic ring of $\mathrm{C}=\mathrm{C}$ \\
\hline & 2250 & $\mathrm{C} \equiv \mathrm{N}$ bonding \\
\hline & $1000-1350$ & $\mathrm{~N}-\mathrm{C}$ bonding \\
\hline & $1550-1640$ & $\mathrm{~N}-\mathrm{H}$ bonding \\
\hline & $1600-1680$ & $\mathrm{C}-\mathrm{C}$ bonding \\
\hline \multirow{5}{*}{ Letrozole -loaded Niosome } & 1125 & $\mathrm{C}-\mathrm{O}$ stretching \\
\hline & 1747 & $\mathrm{C}=\mathrm{O}$ stretching \\
\hline & $2800-3000$ & C-H stretching \\
\hline & 3452 & OH stretching \\
\hline & $1000-1250$ & Aliphatic C-N stretching \\
\hline
\end{tabular}




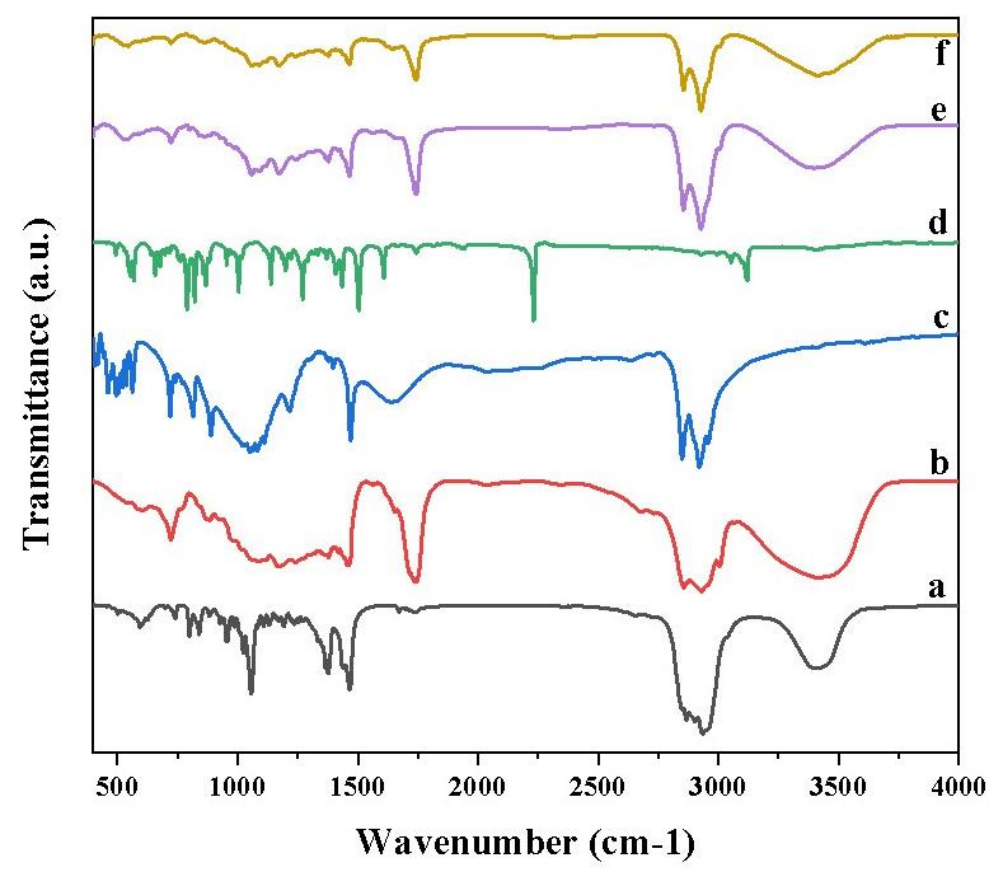

Figure 2. Fourier Transform Infrared FTIR Spectra of (a) Cholesterol, (b) Span80, (c) DCP, (d) Letrozole, (e) Niosome, and (f) Letrozole loaded niosomes.

\subsection{Differential scanning calorimetry (DSC) measurements}

DSC data (Figure 3) revealed that free letrozole has a clearly sharp endotherm peak at 187.6 ${ }^{\circ} \mathrm{C}$ relating to its melting point. However, the DSC thermogram of letrozole loaded niosomes represented a slight difference over $110.2,116.1$ and $234.6^{\circ} \mathrm{C}$, which may result from a change in letrozole structure and can be indicative of inclusion complex formation. 
a

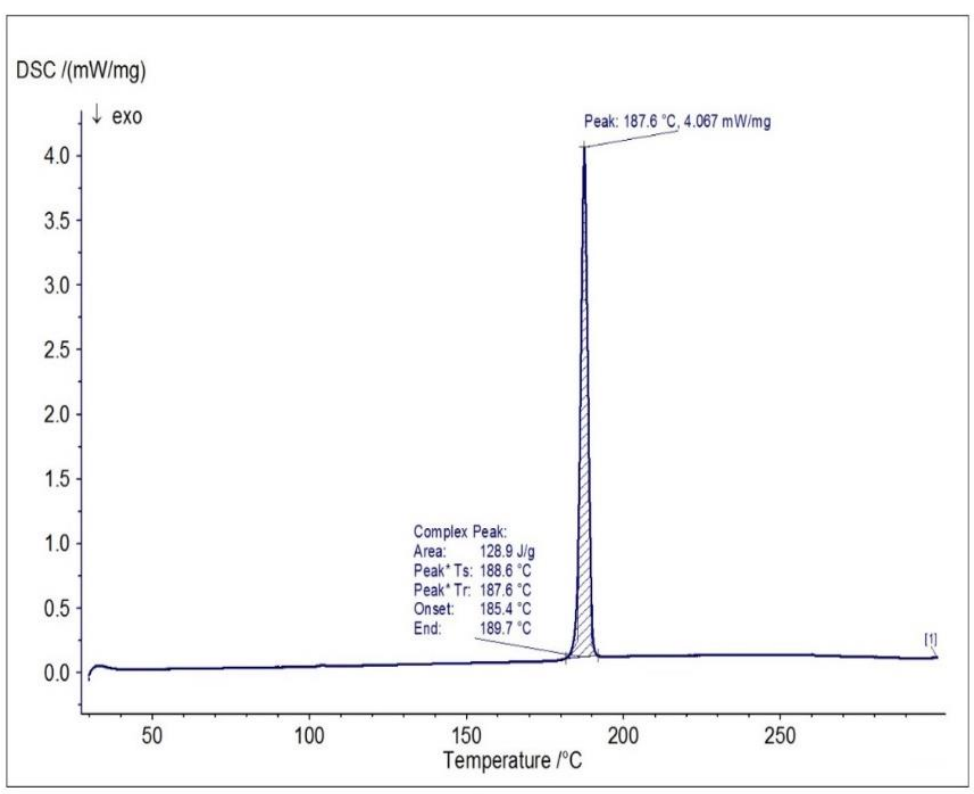

b

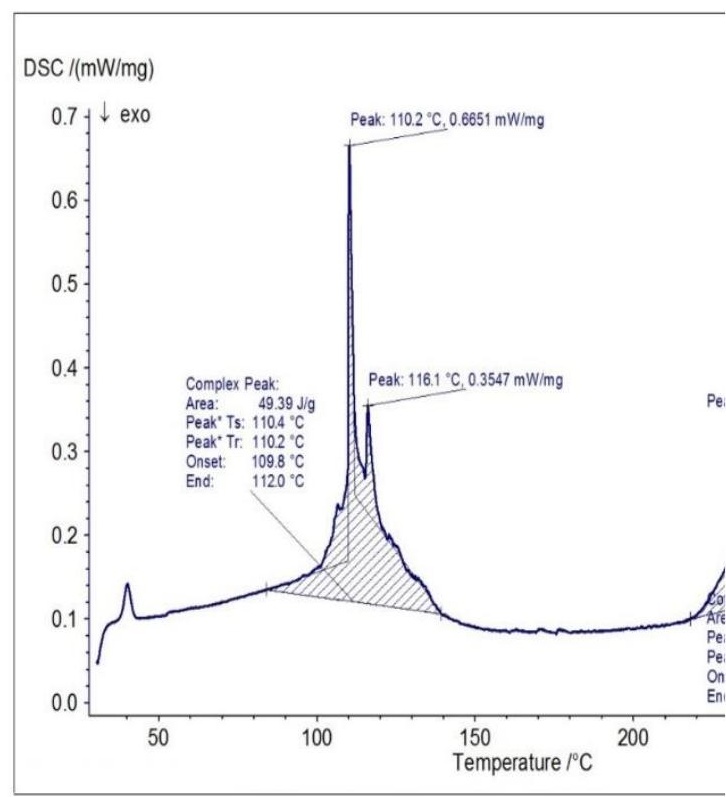

Figure 3.DSC thermograms of (a) Letrozole, (b) Letrozole loaded niosome.

\subsection{Powder X-ray diffractometry (XRD) analysis}

The results obtained from the XRD analysis illustrated that despite the crystalline structure of letrozole, the letrozole loaded niosome showed an almost amorphous structure that confirmed the successful entrapment of the drug into the niosomes (Figure 4). This result was consistent with previous reports of XRD pattern for other formulations. 


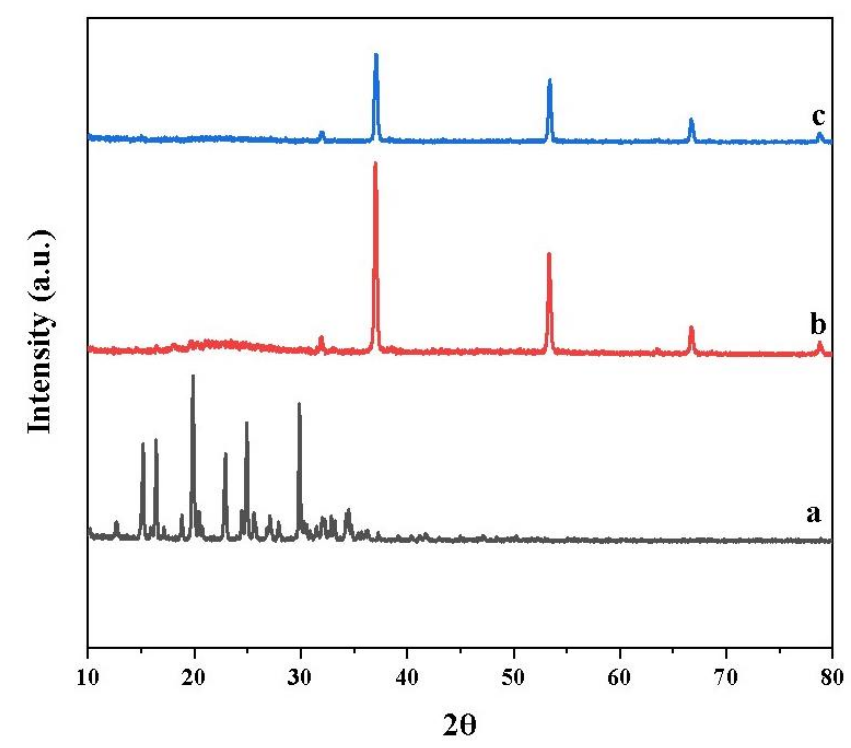

Figure 4. XRD patterns of (a) Letrozole, (b) Niosome, and (c) Letrozole loaded niosome.

\subsection{Drug release study}

This study was carried out to inspect the effect of the niosomes on the releasing rate of the drug from the vesicles. The achievement of a desirable drug release system was another aim of the study obtained using release kinetic models. Figure 5 presented the amount of letrozole retained in the different formulations of niosomes during the specific time intervals. The results revealed that the release of letrozole from niosomal formulations has a biphasic profile; an initial burst of release followed by a constant or slow rate of release. The amounts of drug released from all niosomal formulations were obtained about 33-36\% during the first 8 hours. After this time, the rate of release was constant, and no significant change in the rate of release was observed in all formulations. 


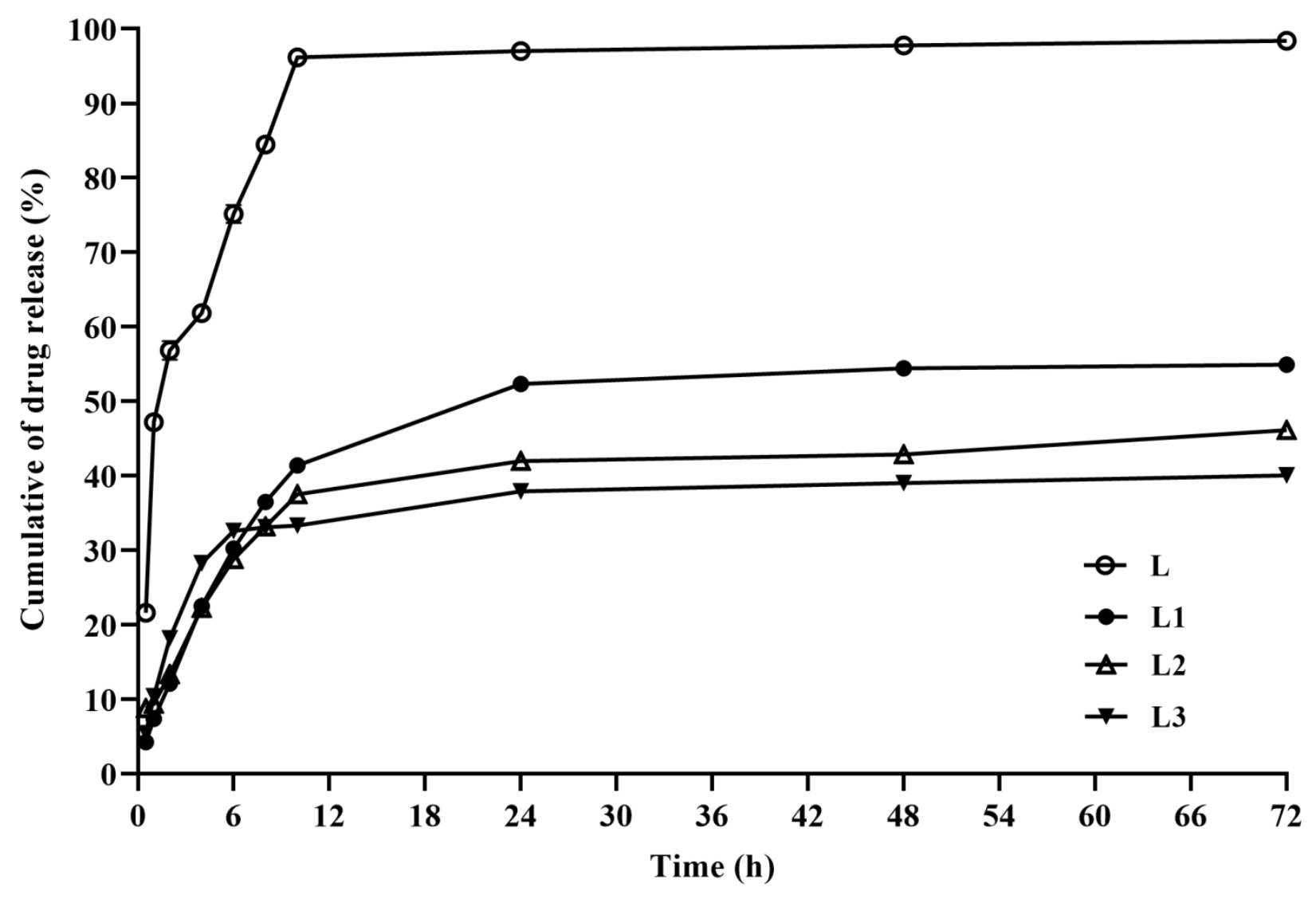

Figure 5. In vitro drug release profile of free letrozole and release profile of letrozole in optimum formulation of letrozole loaded niosomes $\left(\mathrm{L}_{1}, \mathrm{~L}_{2}\right.$ and $\left.\mathrm{L}_{3}\right)$; Data are represented as mean $\pm \mathrm{SD}$.

Linear form of different kinetic models was plotted according to release data, in order to find the release mechanism. To determine the kinetic of release for optimized formulations, the regression coefficient of linear curve was calculated. As the kinetic model with a regression coefficient close to 1 is a desirable model for the release profile, Korsmeyer Peppas was selected as an appropriate model for all prepared niosomal letrozole formulations (Table 5).

Table 5. The release kinetic models and the parameters obtained for niosomal formulations.

\begin{tabular}{llllll}
\hline \multirow{2}{*}{ Release Model } & \multicolumn{4}{l}{ Zero-Order } & \multicolumn{4}{l}{ Korsmeyer-Peppas } & First-Order & Higuchi \\
\cline { 2 - 6 } & $\mathrm{R}^{2}$ & $\mathrm{R}^{2}$ & $\mathrm{~N}$ & $\mathrm{R}^{2}$ & $\mathrm{R}^{2}$ \\
\hline $\mathrm{L}_{1}$ & 0.6083 & 0.8476 & 0.5534 & 0.6789 & 0.8091 \\
\hline $\mathrm{L}_{2}$ & 0.5773 & 0.8775 & 0.3973 & 0.6316 & 0.7760 \\
\hline $\mathrm{L}_{3}$ & 0.4291 & 0.7056 & 0.3728 & 0.6911 & 0.6350
\end{tabular}




\subsection{Physical stability of letrozole-loaded niosomes}

The physical stability of the niosomal formulations was determined by measuring the vesicle size and the retained drug in the niosomes before and after two months of storage at two different temperatures. In all niosomal formulations, the EE\% decreased, whereas the particle size and PDI increased during the storage time. The samples stored at $4 \pm 2{ }^{\circ} \mathrm{C}$ were more stable than the samples stored at $25 \pm 2{ }^{\circ} \mathrm{C}$. The change in particle size, PDI and EE \% of the $\mathrm{L}_{3}$ formulation stored at $4{ }^{\circ} \mathrm{C}$ and $25^{\circ} \mathrm{C}$ in different time intervals was less than in the $\mathrm{L}_{1}$ and $\mathrm{L}_{2}$ formulations. The complete data of stability is represented in the supplementary file. In all formulations, the size of the nanoparticles was changed. Changes in $\mathrm{L}_{1}$ were only significant on days 30 and $60 . \mathrm{L}_{2}$ on days 14,30 , and 60 and L3 only represented significant changes (P-value $<0.05)$ changes in day 30. Moreover, polydispersity index of L1 and L3 was only significant in day 60 whereas PDI of $\mathrm{L}_{2}$ was significantly different in day 30 and 60 for prepared samples which stored and $4 \pm 2{ }^{\circ} \mathrm{C}$ and $25 \pm 2{ }^{\circ} \mathrm{C}$. The capture efficacy (EE) of all formulations was significantly $(\mathrm{P}$-value $<0.05)$ different on day 30 and 60 in both storage conditions (Figure 6).
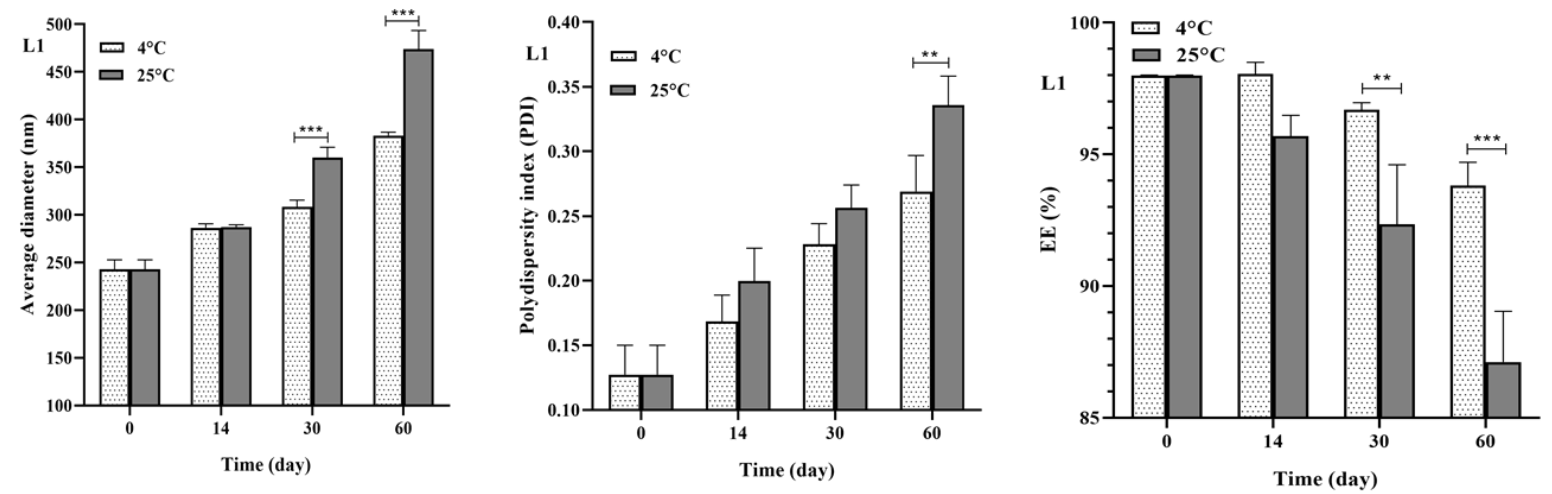

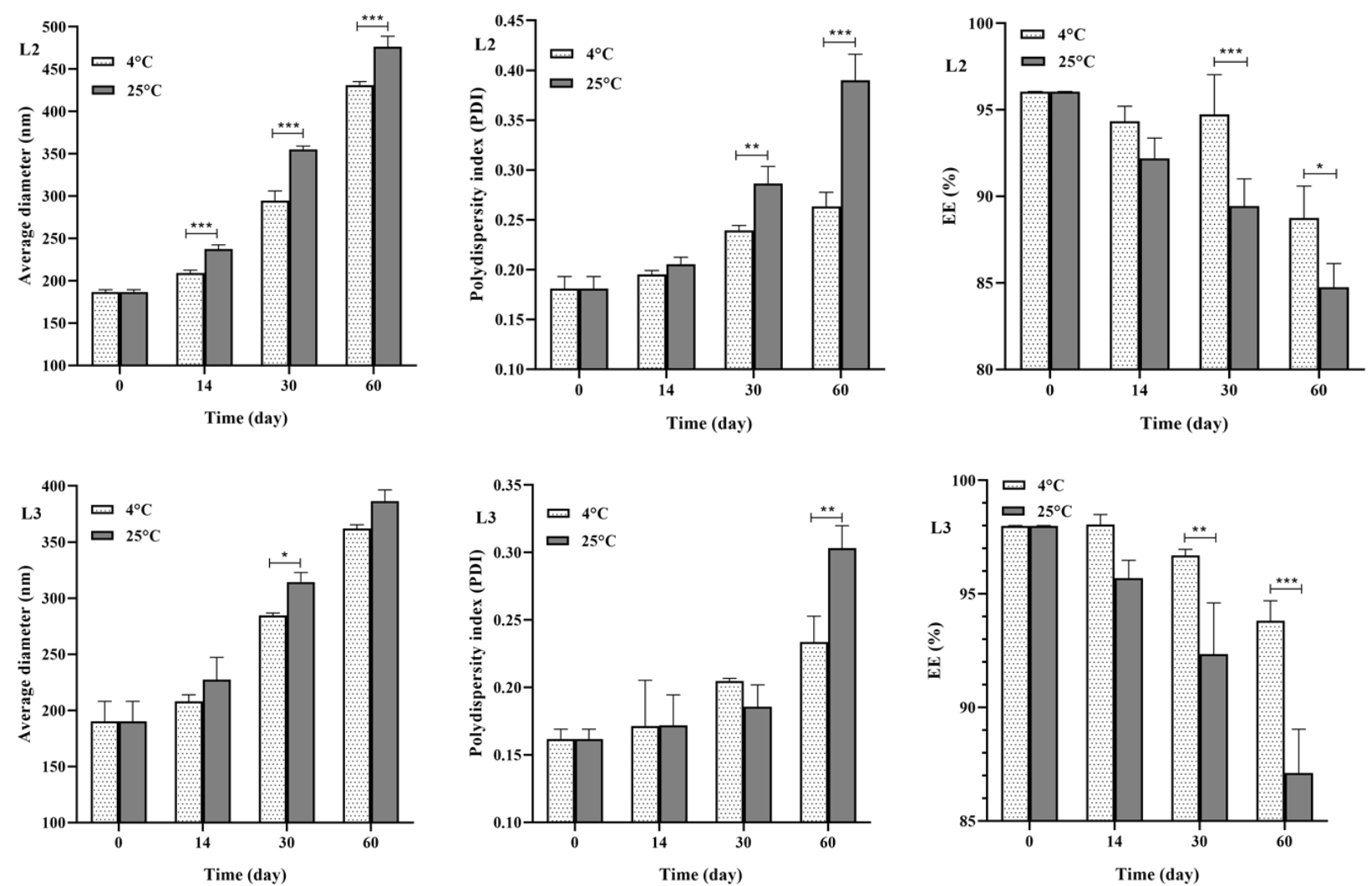

Figure 6. The effect of storage time and storage temperature on the average size, the polydispersity index (PDI), and the encapsulation efficiency of letrozole loaded niosomal formulation $\left(\mathrm{L}_{1}, \mathrm{~L}_{2}\right.$ and $\left.\mathrm{L}_{3}\right)$; Data are represented as mean $\pm \mathrm{SD}$ and $\mathrm{n}=3 ; \mathrm{P}<0.001 * * *$, $\mathrm{P}<0.01 * *, \mathrm{P}<0.05 *$.

\subsection{In vitro cell viability}

The MTT assay was performed to investigate the antiproliferative effects of different formulations of niosomes ( $\mathrm{L}_{3 \mathrm{~B}}, \mathrm{~L}, \mathrm{~L} 3$ and $\left.\mathrm{L}_{+} \mathrm{L}_{3}\right)$ on cancer cells. As presented in Figure 7a, b a significant decrease was observed in cell viability of cancer cells after $48 \mathrm{~h}$ of treatment with $\mathrm{L}, \mathrm{L} 3$, and $\mathrm{L}+\mathrm{L}_{3}$ compared to $72 \mathrm{~h}$ of treatment. Treatment of cancer cells with $\mathrm{L}, \mathrm{L} 3$, and $\mathrm{L}+\mathrm{L}_{3}(1: 2 \mathrm{v} / \mathrm{v})$ showed dose-dependent toxicity. Significant decrease in cell viability was obtained for the $\mathrm{L}_{3}$ and $\mathrm{L}+\mathrm{L}_{3}(1: 2 \mathrm{v} / \mathrm{v})$ formulations compared to the free drug (Figure 7a, b). Therefore, it seems that the $\mathrm{L}_{3}$ and $\mathrm{L}+\mathrm{L} 3(1: 2 \mathrm{v} / \mathrm{v})$ formulations improved the antiproliferative activity of the drug. Drug-free niosomes $\left(\mathrm{L}_{3 \mathrm{~B}}\right)$ showed negligible 
cytotoxicity against MCF-7, MDA-MB-231, and MCF10A cells (Figure 7c). The results revealed that $\mathrm{L}_{3}$ did not have significant toxicity in MCF10A cells after 48 and $72 \mathrm{~h}$ of treatment (Figure 7d), indicating that they have enough biocompatibility to use as a drug delivery system. $\mathrm{IC}_{50}$ values were calculated as $\mu \mathrm{g} / \mathrm{ml}$ for $\mathrm{L}, \mathrm{L}_{3}$ and $\mathrm{L}+\mathrm{L}_{3}$, respectively.
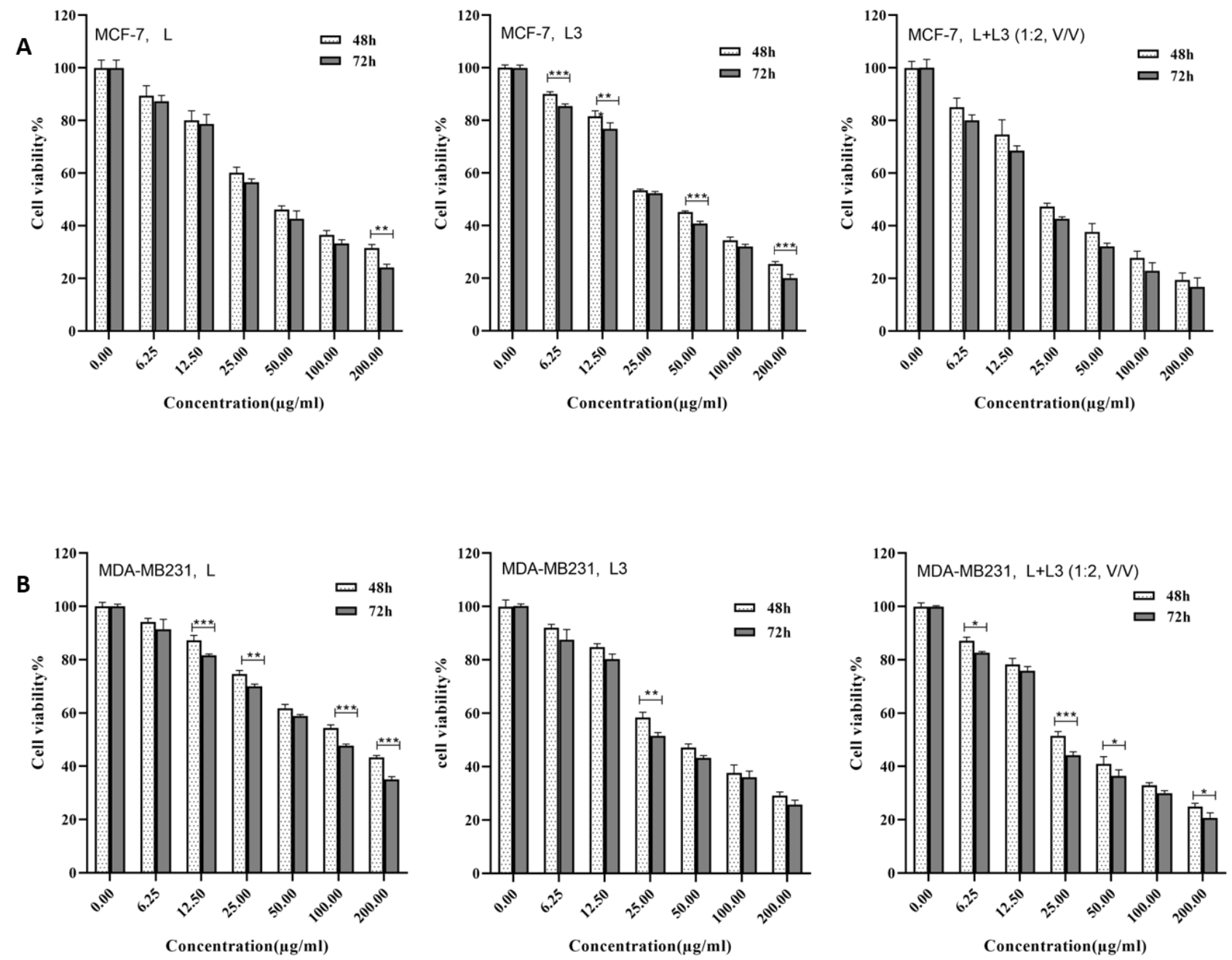

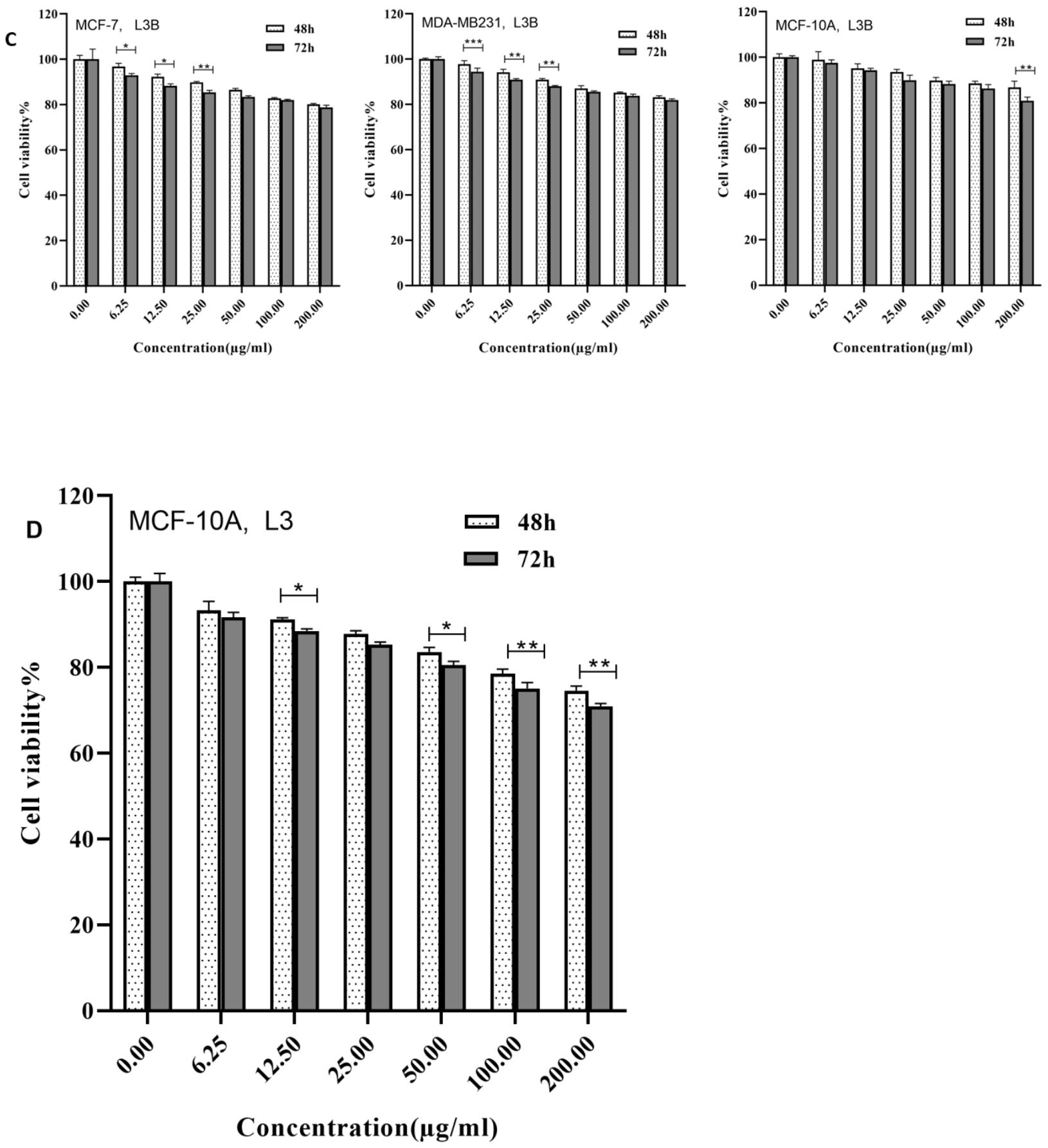

Figure 7. The drug concentration effect on the viability of A) MCF-7 cells, B) MDA-MB231 cells. C) The effect of $\mathrm{L}_{3 \mathrm{~B}}$ on the viability of MCF-7 cells, MDA-MB-231 and MCF10A cells. D) The effect of L3 on the viability of MCF10A cells; Data are represented as mean \pm $\mathrm{SD}$ and $\mathrm{n}=3 ; \mathrm{P}<0.001 * * *, \mathrm{P}<0.01 * *, \mathrm{P}<0.05 *$.

As indicated in Figure 8, there is a significant decrease $(\mathrm{P}<0.05)$ between $\mathrm{IC}_{50}$ of the $\mathrm{L}$ formulation compared to the $\mathrm{L}_{3}$ and $\mathrm{L}+\mathrm{L}_{3}$ formulations in both breast cancer cells at 48 and 72 hours (Figure 8a). Furthermore, $\mathrm{IC}_{50}$ of all formulations were decreased as time- 
dependent manner for both MCF-7 and MDA-MB-231 cells. This decrease was significant for the $\mathrm{L}$ and $\mathrm{L}_{3}$ formulations, but not for the $\mathrm{L}+\mathrm{L} 3$ formulation (Figure 8b). L $\mathrm{L}_{3 \mathrm{~B}}, \mathrm{~L}$ and $\mathrm{L} 3$ IC50 on MCF10A cells were obtained higher than $200 \mu \mathrm{g} / \mathrm{ml}$.
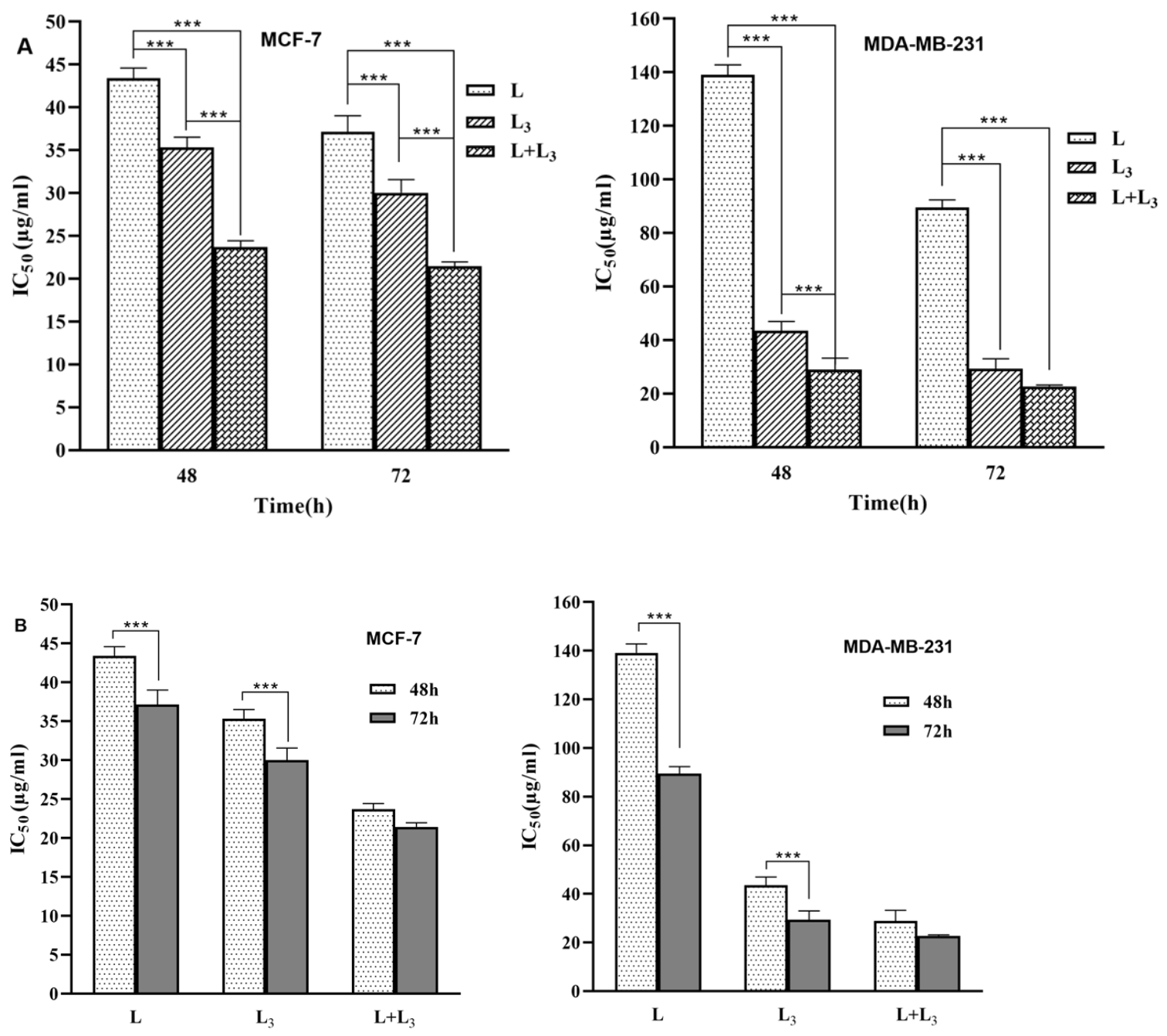

Figure 8. IC50 values for different sample using MTT assay. A) in the different formulations, B) in the different time points. Data are represented as mean \pm SD and $n=3$; $\mathrm{P}<0.001 * * *$. 


\subsection{Apoptotic gene expression analysis}

The expression of apoptosis-related genes $\left(B A X, B C L_{2}\right.$ and P53) in treated cancerous cells at transcription levels, were studied by real-time PCR. Comparison between gene expressions in cancer cell lines (MCF-7, MDA-MB-231) and control group indicated a significant increase in the expression level of pro-apoptotic Bax and P53 genes and a remarkable decrease in the expression of anti-apoptotic $B C L_{2}$ gene, after $72 \mathrm{~h}$ exposure to the $\mathrm{L}, \mathrm{L}_{3}$, and $\mathrm{L}+\mathrm{L}_{3}(1: 2 \mathrm{v} / \mathrm{v})$ formulations (Figure 9). Furthermore, the expression level of $B A X$ and $P 53$ in cancer cells treated with $\mathrm{L}_{3}$ and $\mathrm{L}+\mathrm{L} 3(1: 2 \mathrm{v} / \mathrm{v})$ was significantly higher than that of the $\mathrm{L}$ formulation. A significantly lower level of BCL2 expression was obtained for cells treated with $\mathrm{L}_{3}$ and $\mathrm{L}+$ L3 (1: $2 \mathrm{v} / \mathrm{v})$, while a higher level of expression was achieved for the L formulation (Figure 9).
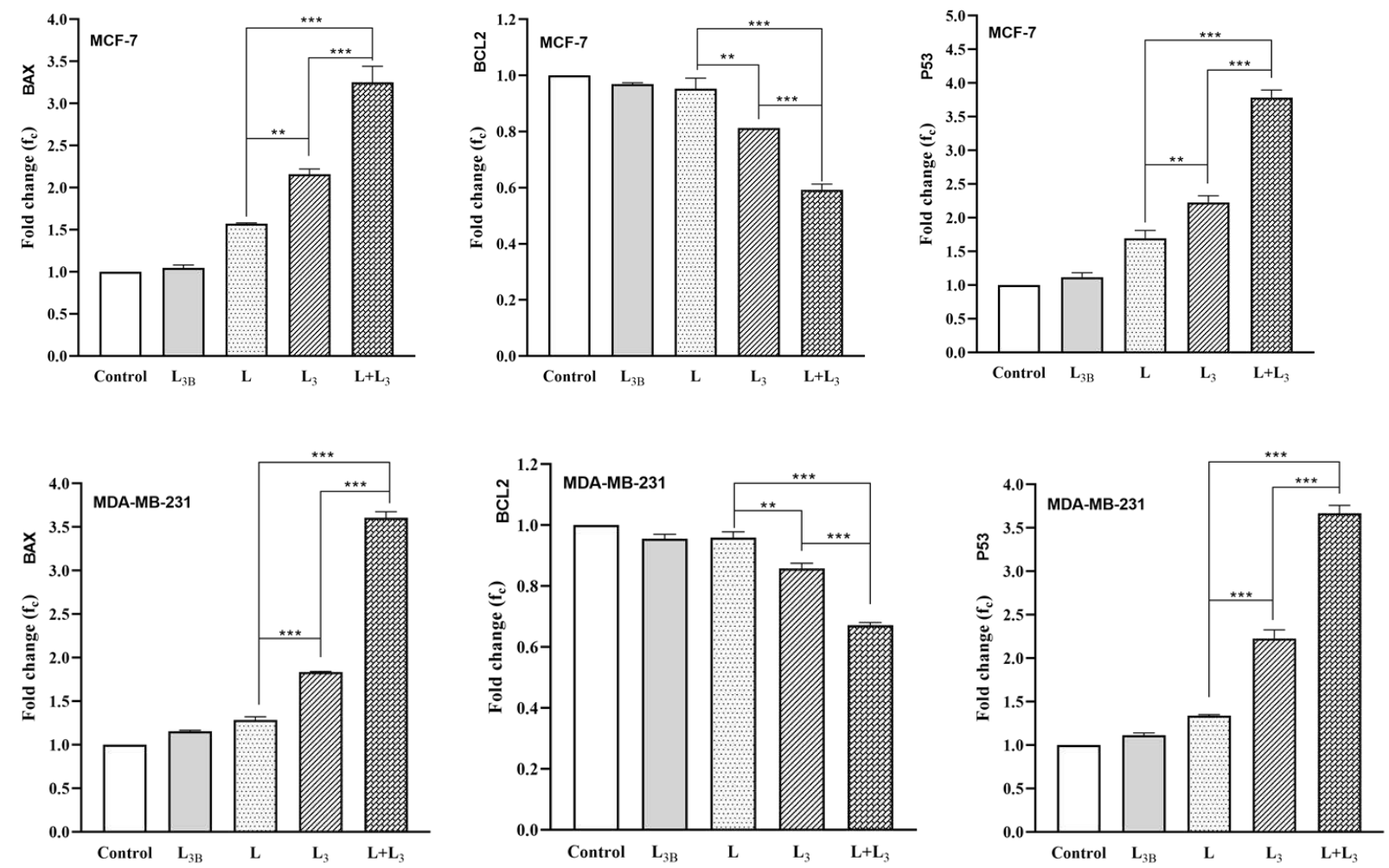

Figure 9. The expression of $B A X, P 53$ and $B C L_{2}$ genes in MCF-7 and MDA-MB-231 cells after treatment with different samples. The $\mathrm{IC}_{50}$ was used for each sample; Data are represented as mean $\pm \mathrm{SD}$ and $\mathrm{n}=3 ; \mathrm{P}<0.001 * * *, \mathrm{P}<0.01 * *$. 


\subsection{Apoptosis study}

The Annexin-PI staining by flow cytometry was used to study the cytotoxicity, apoptosis and necrosis of the breast cancer treated by different formulations of letrozole. In this regard, the MCF-7 and MDA-MB-231 cells were treated for $72 \mathrm{~h}$ with $\mathrm{L}_{3 \mathrm{~B}}, \mathrm{~L}, \mathrm{~L}_{3}$ and $\mathrm{L}_{+} \mathrm{L}_{3}(1: 2 \mathrm{v} / \mathrm{v})$ formulations at their $\mathrm{IC}_{50} \mathrm{~s}$. As illustrated in Figure 10, the apoptosis rate of MCF-7 and MDA-MB-231 cells which treated by letrozole solution (L) was about $15.505 \%$ and 15.96 $\%$, respectively. The rate of apoptosis of MCF-7 and MDA-MB-231 cells treated with $\mathrm{L}_{3}$ was approximately $23.86 \%$ and $25.665 \%$, respectively, and this rate for MCF-7 and MDA-MB231 cells treated with L + L3 (1: $2 \mathrm{v} / \mathrm{v})$ was obtained around $38.70 \%$ and $44.665 \%$, respectively. The rate of apoptosis for the cells treated by $\mathrm{L}_{3}$ and $\mathrm{L}+\mathrm{L}_{3}(1: 2 \mathrm{v} / \mathrm{v})$ was significantly greater than that of treated by L and control groups (Figure 11).
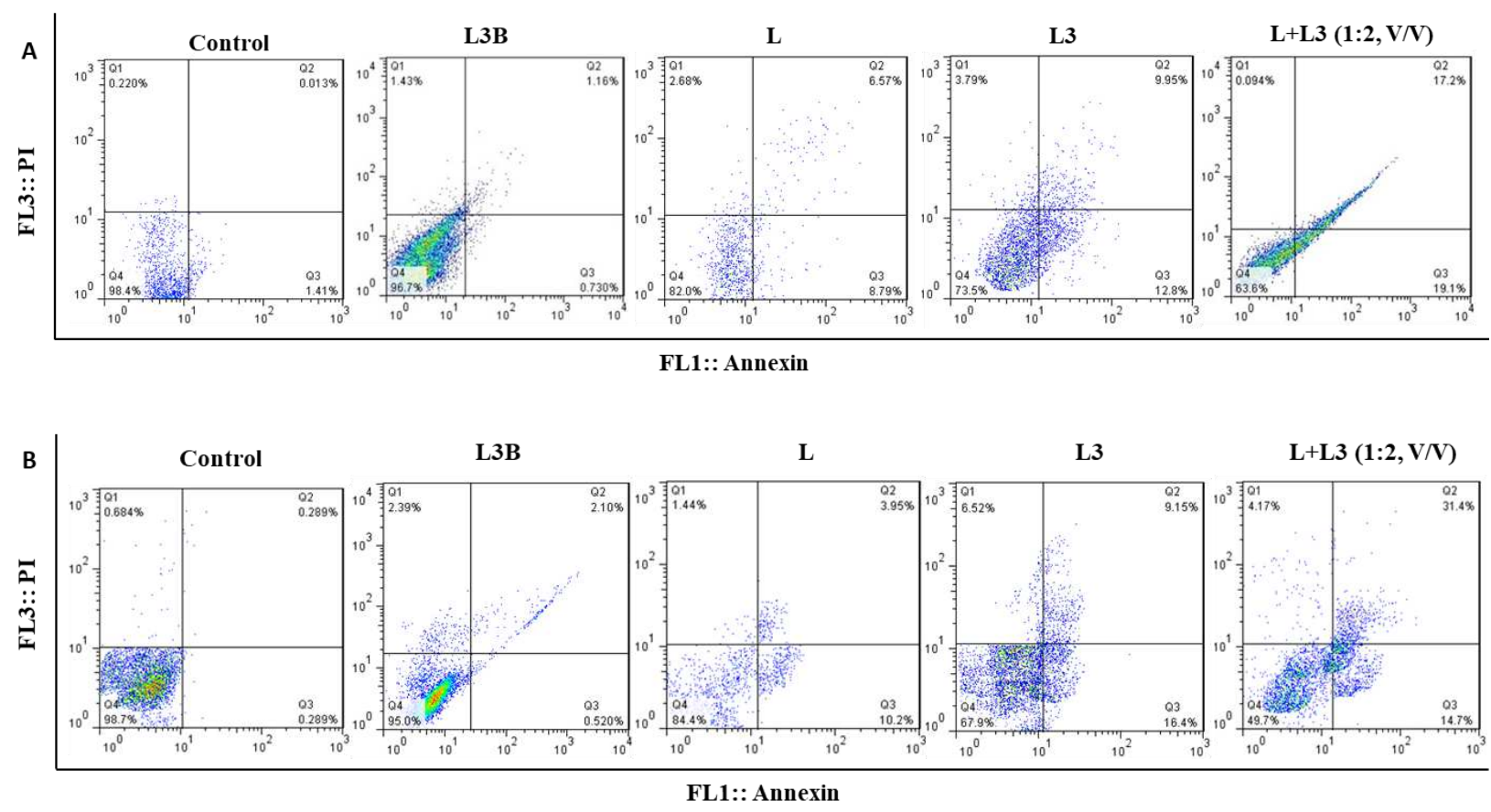

Figure 10. The flow cytometry of A) MCF-7 and B) MDA-MB-231 cells after treatment with different samples. Different quadrants in the scatter plot of double variable flow cytometry could reveal the following information: the Q1 quadrant (FITC-/PI+): necrotic cells; the Q2 quadrant (FITC+/PI+): late apoptotic cells; Q3 quadrant (FITC+/PI-): early apoptotic cells; and the Q4 quadrant (FITC-/PI-): living cells; Data are represented as mean $\pm \mathrm{SD}$. 

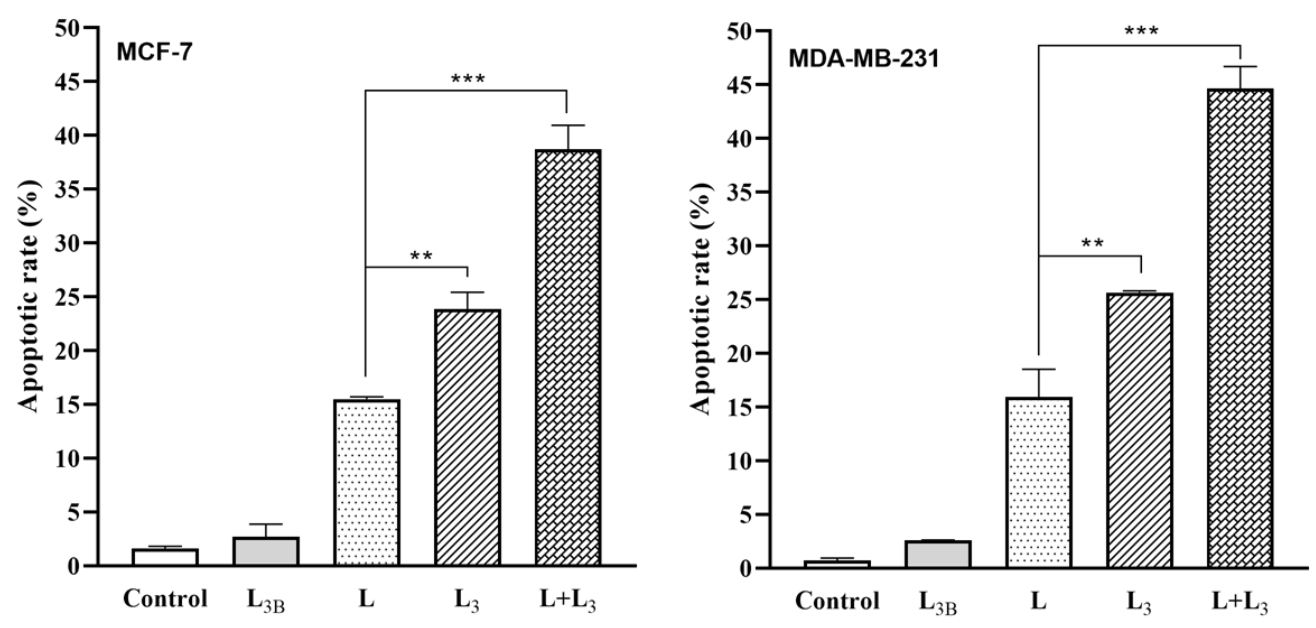

Figure 11. The quantitative apoptosis rate analysis of MCF-7 cells and MDA-MB-231 cells after treatment with different samples; Data are represented as mean \pm SD and $n=3$; $\mathrm{P}<0.001 * * *, \mathrm{P}<0.01 * *$.

\subsection{Cell cycle analysis}

The impact of different formulations of letrozole on cell cycle progression in the breast cancer cells was investigated by flow cytometry (Figure 12 and Figure 13). As demonstrated in Figure 13, treatment with L, L3, and L + L3 (1:2 v/v) formulations, led to arresting cells in the sub-G1 phase of the cell cycle in both breast cancer cells. The amount of sub-G1 cell population in MCF-7 cells treated with $\mathrm{L}, \mathrm{L}_{3}$ and $\mathrm{L}+\mathrm{L}_{3}(1: 2 \mathrm{v} / \mathrm{v})$ was obtained about $5.32 \%$, $9.985 \%$ and $16.335 \%$, respectively. This amount for MDA-MB-231 cells treated with L, L3, and $\mathrm{L}+\mathrm{L} 3(1: 2 \mathrm{v} / \mathrm{v})$ was around $7.335 \%, 12.535 \%$, and $18.73 \%$, respectively. These results were in agreement with the results of apoptosis study in which higher apoptosis rate was observed in MDA-MB-231 cells with higher impact for $\mathrm{L}+\mathrm{L}_{3}(1: 2 \mathrm{v} / \mathrm{v})$ formulation. 


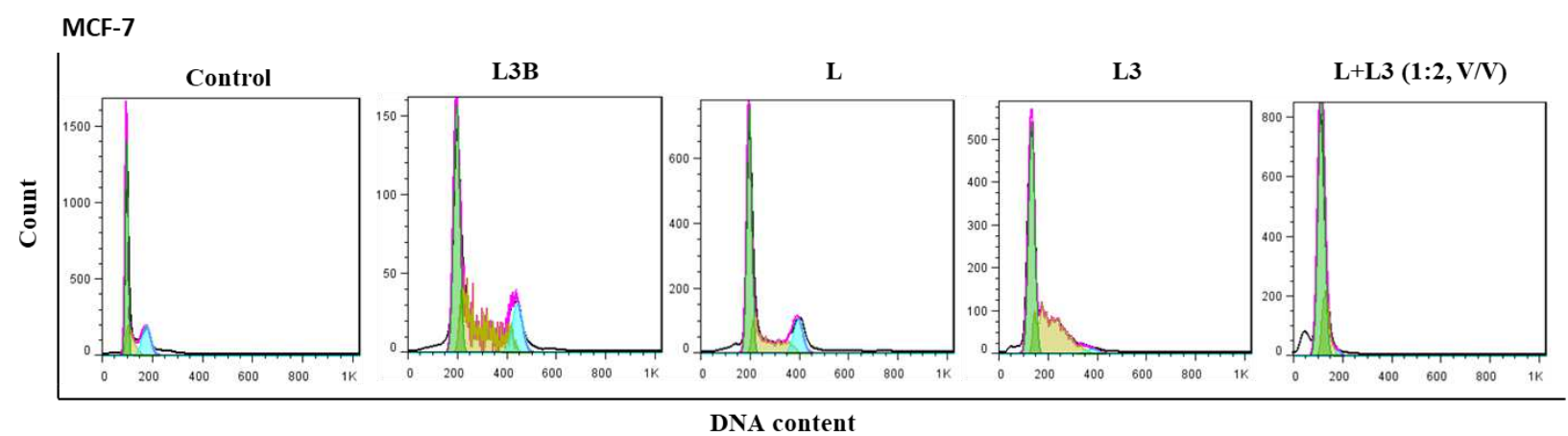

IES-gM-AOM

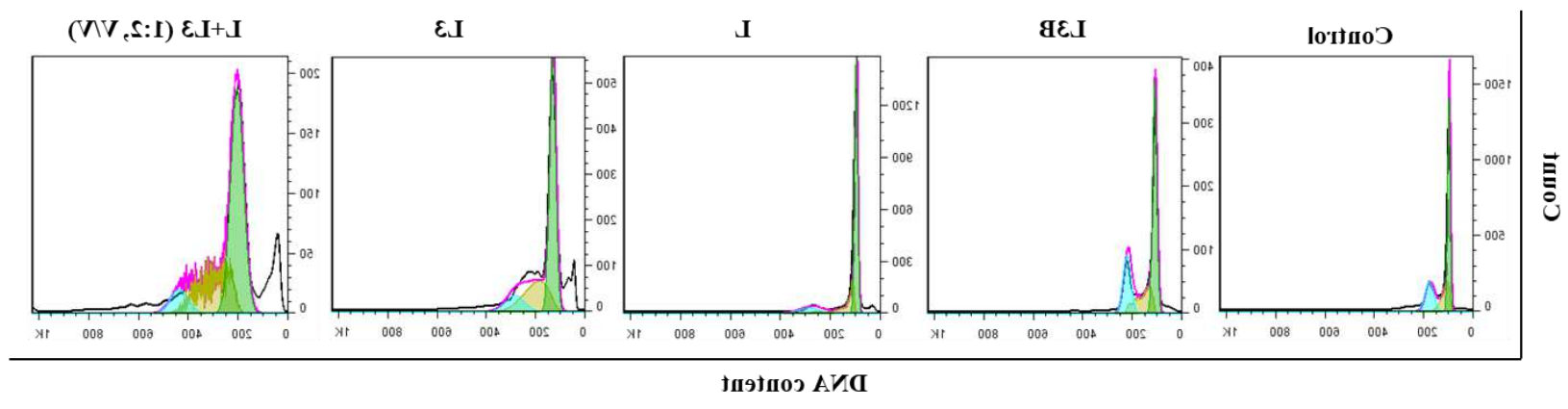

Figure 12. Cell cycle analysis of MCF-7 and MDA-MB-231 cells treated by different formulations of niosomes by the same concentration of the drug.
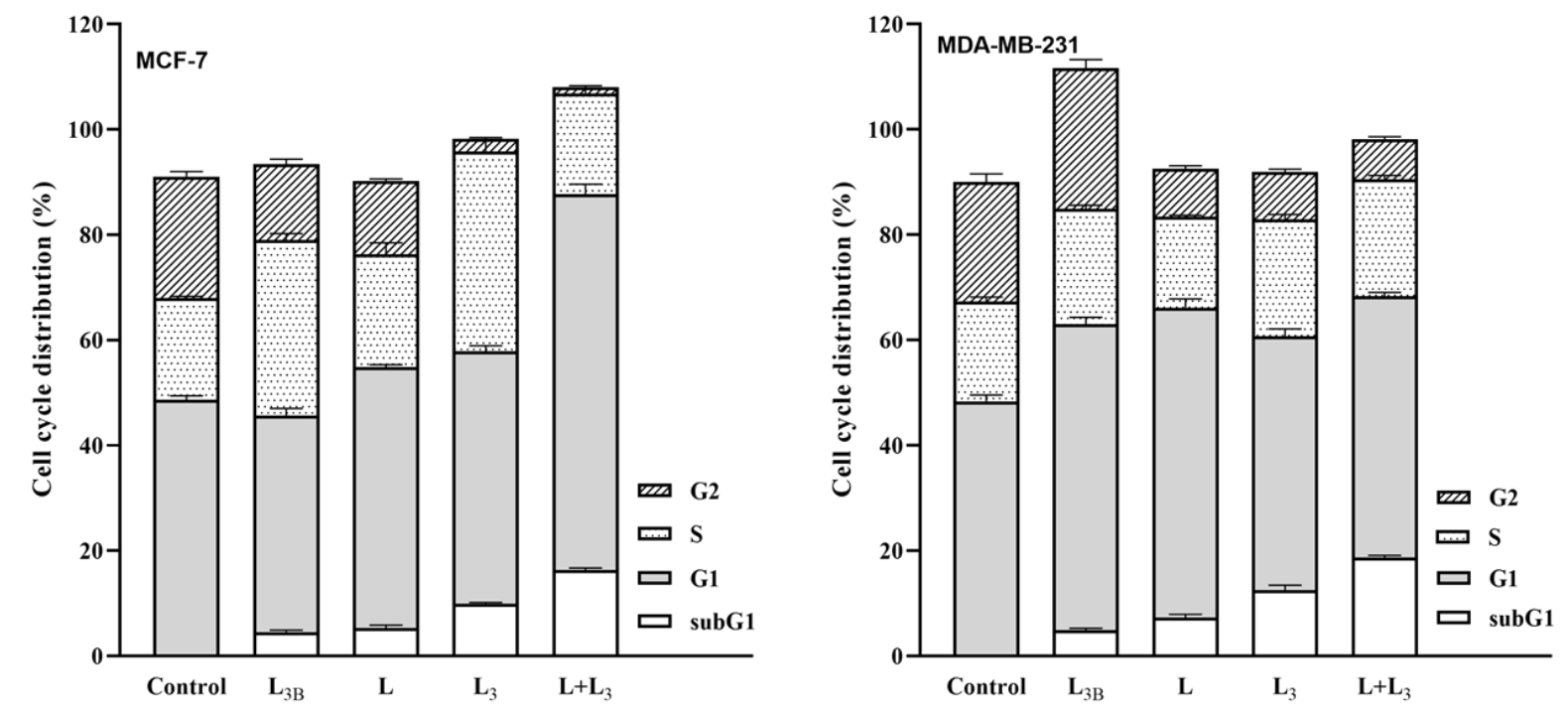

Figure 13. Cell cycle distribution for MCF-7 cells and MDA-MB-231 cells after treatment with different samples. The control sample refers to the cells without treatment with any drug or nanomaterial; Data are represented as mean \pm SD. 


\section{Discussion}

As illustrated in Table 3, niosomal formulations with different lipid-to-drug molar ratios and also surfactant type was exhibited with various size and PDI. The entrapment efficiency and particle size strongly depend on the type of surfactants and the amount of cholesterol (i.e., lipid) in the niosomal structure because any change in chemical type and chemical composition directly affects the hydrophilic-lipophilic balance (HLB) in the niosomal formulation ${ }^{[22-25]}$. The smaller size of the 80 -span niosomes may be attributed to the length of the hydrophobic chain of this surfactant and the more hydrophilic-hydrophobic interaction between the encapsulated letrozole, cholesterol, DCP, and the hydrophobic chain of the surfactant ${ }^{[19]}$. The prepared niosomes with a lipid-to-drug ratio of 10 showed a considerably smaller size compared to those with a lipid-to-drug ratio of 20 . These results were in agreement with other studies ${ }^{[20]}$ which have indicated that a higher amount of lipid in the niosomal formulation might result in a thicker lipid bilayer and larger nanoparticles ${ }^{[20]}$. The size of the particles is a crucial parameter for efficient drug delivery, which can affect the entrapment efficiency and drug release. This study confirmed that the amount of cholesterol could significantly affect the mean size of the niosomes, which was according to previous reports, that is, increasing the amount of cholesterol; the size of the vesicles was increased ${ }^{[26-}$ 30].

The polydispersity index illustrates the uniformity of particle size and is a criterion for the width of the size distribution ${ }^{[31]}$. The PDI value varies between 0 and 1 , and the lower PDI value belongs to the more homogeneous suspension. The uniform particles have a narrow size distribution and low tendency to aggregate ${ }^{[32]}$. Our results indicated that probe sonication decreases the particle size of the niosomes and a higher amount of cholesterol, which leads to lower entrapment efficiency of the drug. These findings were in agreement with previous reports ${ }^{[26,27]}$. It seems that beyond a certain level of cholesterol, the bilayer 
structure may be altered and the amount of drug retained may be reduced ${ }^{[28]}$. Therefore, an optimal cholesterol ratio should be selected to achieve a high amount of drug loading and niosome stability ${ }^{[32,33]}$.

The size of the vesicles measured by SEM and TEM, were smaller than those of measured by Nano Zetasizer (DLS). This difference may be related to the drying process during the SEM and TEM imaging. In other words, SEM and TEM give the mean size of dried nano particles (measures the exact diameter of each particle). However, DLS measures the hydrodynamic diameter that includes core plus any molecule attached or adsorbed on the surface, including ions and water molecules ${ }^{[29,30,34,35]}$

The rate of drug release depends on the composition and fluidity of the bilayer membrane. Moreover, electrostatic interactions between drug and surfactants are essential, mainly when the drug exists in an ionized form at physiologic $\mathrm{pH}^{[36]}$. The initial phase involves the almost accelerated release of letrozole and then followed by a more passive release phase. The rapid initial release can be attributed to the release of loosely attached drug molecules on the surface of the vesicles and the slower phase is fundamentally related to the diffusion of letrozole through the bilayers ${ }^{[37-39]}$. According to the $\mathrm{R}^{2}$ values of the release kinetic models in Table $\mathbf{5}$, it was found that drug release is controlled by diffusion and erosion mechanisms ${ }^{[20,40,41]}$, and the values of $\mathrm{n}(0.43$ $<\mathrm{n}<0.85)$ indicate that drug release is based on Fickian diffusion release ${ }^{[35,42]}$. More stability of the niosomes stored at $4 \pm 2{ }^{\circ} \mathrm{C}$ is possibly due to less mobility of bilayer at this temperature ${ }^{[20,43,44]}$. Increasing the size of the vesicle during storage may be related to its fusion ${ }^{[45]}$ or aggregation ${ }^{[46]}$. Also, the decrease in EE\% at high temperatures may be due to more fluidization of the lipid vesicles and drug leakage ${ }^{[47,48]}$. In addition to this, due to the irregularity of the surfactant fatty acid chain at high temperatures, the thickness of the two layers decreases and leads to more drug diffusion from the vesicles ${ }^{[43]}$. Also, at high 
temperature, the fatty acid chain of the surfactants gets irregular configuration so that, the bilayer thickness decreases and the rate of diffusion across the bilayer membrane increases [43].

Treatment of cancer cells with a letrozole-loaded niosome and a letrozole-loaded niosome showed a correlation between dosage and toxicity. Interestingly, the results showed that cytotoxicity effect of free letrozole was lower than the letrozole loaded niosome at the same concentration. A possible explanation for these findings is that the antiproliferative activity of drug has been enhanced by niosomal encapsulation. As expected, drug-free niosomes showed no cytotoxicity against treated cells. It confirmed that the niosomes are biocompatible enough to be used as a drug delivery system. Flow cytometric results indicated that the cytotoxicity of letrozole and letrozole loaded niosomes on MDA-MB-231 cells was conducted through induction of apoptosis. Therefore, the niosome preparation process had no effect on the mechanism of action of the drug. These results are consistent with those of other studies that state that cancer cell progression and growth depend on the balance between pro- and antiapoptotic proteins, including the Bax and BCL-2 genes ${ }^{[49,50]}$. The expression level of P53 increased remarkably. It was shown that P53 plays a role as a regulator of the Bax to BCL-2 ratio in the cell by increasing the expression of pro-apoptotic proteins such as Bax and Bid. Furthermore, interaction between P53 with proteins of the BCL-2 family leads to the activation and translocation of Bax and Bid to the outer membrane of mitochondria. P53 also translocates directly to mitochondria to activate the mitochondrial apoptosis pathway ${ }^{[51-53]}$. Cell localization is an important feature of nanoparticles that has been investigated in previous studies. For instance, mesoporous silica NPs could enter the cells and remain for a long time which is enough to allow the release of drug from NPs ${ }^{[54]}$. Other studies also showed that polymeric NPs could enter the cancer cells, diffuse in the cytoplasm and, escape from endosomal degradation ${ }^{[33,54,55]}$. Confocal microscopy studies showed that free 
doxorubicin accumulated in the cell membrane and entered the cell slowly through a diffusion pathway, while encapsulated doxorubicin was mainly localized in the cytoplasm through the endocytosis pathway ${ }^{[56]}$. Silibinin, cisplatin, and vinblastine loaded niosomes had a higher cytotoxicity than free drugs in T-47D, TC-1, and BT-20 cancer cells, respectively ${ }^{57-}$

59]. These reports support the current conclusion due to our observations by confocal microscopy, namely, higher toxicity and apoptotic rate of the letrozole-loaded niosomes attributed to the higher delivery efficiency of drug-loaded niosomes into cancer cells.

\section{Conclusions}

This study provided evidence that the use of niosomes as a drug carrier can enhance the anticancer activity of letrozole against human breast cancer cells. In this regard, niosomes were successfully prepared and optimized in terms of vesicle size, PDI, EE, and drug release pattern. The prepared niosomes showed appropriate morphology and stability. Biological activity of encapsulated letrozole was enhanced due to improvement in drug stability and physicochemical properties. In vitro studies showed that letrozole-loaded niosomes induced apoptosis in both breast cancer cells (MCF-7 and MDA-MB-231), which could be the result of down-regulation or up-regulation of genes related to apoptosis (BAX, BCL2, and P53). Localization of nanoparticles inside the cells and interaction between nanoparticles and living cells are very important in nanotechnology-based intracellular delivery of poor water-soluble drugs. Intercellular localization and long persistence of niosomes inside the cancer cells could enhance the therapeutic efficiency of niosomal formulations. The results of this study would develop a new view for further studies and effective methods to design the anticancer drugs. 


\section{Acknowledgments}

The authors would like to acknowledge the Pasteur Institute of Iran for providing the necessary laboratory facilities for this study.

\section{Declaration of interest}

The authors declare that they have no conflict of interest.

\section{References}

[1] Seleci, M.; Seleci, D. A.; Joncyzk, R.; Stahl, F.; Blume, C.; Scheper, T. Smart multifunctional nanoparticles in nanomedicine. BioNanoMaterials. 2016, 17, 33-41. DOI: 10.1515/bnm-2015-0030.

[2] Akbarzadeh, I.; Saremi Poor, A.; Yaghmaei, S.; Norouzian, D.; Noorbazargan, H.; Saffar, S.; Ahangari Cohan, R.; Bakhshandeh, H. Niosomal delivery of simvastatin to MDA-MB-231 cancer cells. Drug Dev. Ind. Pharm. 2020, 46, 1535-1539. DOI: 10.1080/03639045.2020.1810269.

[3] Mahale, N.; Thakkar, P.; Mali, R.; Walunj, D.; Chaudhari, S. Niosomes: novel sustained release nonionic stable vesicular systems-an overview. Adv. colloid interface sci. 2012, 183, 46-54. DOI: 10.1016/j.cis.2012.08.002.

[4] Akbarzadeh, I.; Yaraki, M. T.; Ahmadi, S.; Chiani, M.; Nourouzian, D. Folic acidfunctionalized niosomal nanoparticles for selective dual-drug delivery into breast cancer cells: An in-vitro investigation. Adv. Powder Technol. 2020, 31, 4064-4071. DOI: 10.1016/j.apt.2020.08.011.

[5] Shad, P. M.; Karizi, S. Z.; Javan, R. S.; Mirzaie, A.; Noorbazargan, H.; Akbarzadeh, I.; Rezaie, H. Folate conjugated hyaluronic acid coated alginate nanogels encapsulated oxaliplatin enhance antitumor and apoptosis efficacy on colorectal cancer cells (HT29 cell line). Toxicol. in Vitro. 2020, 65, 104756. DOI: 10.1016/j.tiv.2019.104756.

[6] Shirzad, M.; Jamehbozorgi, S.; Akbarzadeh, I.; Aghabozorg, H. R.; Amini, A. The role of polyethylene glycol size in chemical spectra, cytotoxicity, and release of PEGylated nanoliposomal cisplatin. Assay Drug Dev. Technol. 2019, 17, 231-239. DOI: $10.1089 /$ adt.2019.923.

[7] Akbarzadeh, I.; Fatemizadeh, M.; Heidari, F.; Niri, N. M. Niosomal Formulation for Co-Administration of Hydrophobic Anticancer Drugs into MCF-7 Cancer Cells. Arch. Adv. Biosci. 2020, 11, 1-9. DOI: 10.22037/aab.v11i2.28906.

[8] Akbarzadeh, I.; Yaraki, M. T.; Bourbour, M.; Noorbazargan, H.; Lajevardi, A.; Shilsar, S. M. S.; Heidari, F.; Mousavian, S. M. Optimized doxycycline-loaded niosomal formulation for treatment of infection-associated prostate cancer: An invitro investigation. J. Drug Deliv. Scie. Technol. 2020, 57, 101715. DOI: 10.1016/j.jddst.2020.101715.

[9] Akbarzadeh, I.; Keramati, M.; Azadi, A.; Afzali, E.; Shahbazi, R.; Norouzian, D.; Bakhshandeh, H. Optimization, physicochemical characterization, and antimicrobial activity of a novel simvastatin nano-niosomal gel against E. coli and S. aureus. Chem. Phys. Lipids. 2021, 234, 105019. DOI: 10.1016/j.chemphyslip.2020.105019. 
[10] Akbarzadeh, I.; Shayan, M.; Bourbour, M.; Moghtaderi, M.; Noorbazargan, H.; Eshrati Yeganeh, F.; Saffar, S.; Tahriri, M. J. B. Preparation, Optimization and InVitro Evaluation of Curcumin-Loaded Niosome@ calcium alginate nanocarrier as a new approach for breast cancer treatment. Biology (Basel). 2021, 10, 173. DOI: 10.3390/biology10030173.

[11] Moammeri, A.; Jamshidifar, E.; Abbaspour, K.; Sadeghi, S.; Lamakani, L.; Akbarzadeh, I. Synergistic effect of curcumin-Cu and curcumin-Ag nanoparticle loaded niosome: Enhanced antibacterial and anti-biofilm activities. Bioorg. Chem. 2021, 105116. DOI: 10.1016/j.bioorg.2021.105116.

[12] Naseroleslami, M.; Niri, N. M.; Akbarzade, I.; Sharifi, M.; Aboutaleb, N. Simvastatin-loaded nano-niosomes confer cardioprotection against myocardial ischemia/reperfusion injury. Drug Deliv. Transl. Res. 2021, 1-10. DOI: 10.1007/s13346-021-01019-z.

[13] Yuksel, N.; Bayindir, Z. S.; Aksakal, E.; Ozcelikay, A. T. In situ niosome forming maltodextrin proniosomes of candesartan cilexetil: In vitro and in vivo evaluations. Int. J. Biol. Macromol. 2016, 82, 453-463. DOI: 10.1016/j.ijbiomac.2015.10.019.

[14] Mehrabi, M. R.; Norouzian, D.; Shokrgozar, M. A.; Toliyat, T.; Chiani, M.; Farhangi, A.; Alambin, F.; Akbarzadeh, A. Pegylated niosomal nanoparticles loaded with vincristine: Characterization and in vitro evaluation. Trop. J. Pharm. Res. 2017, 16, 975-980. DOI:10.4314/tjpr.v16i5.2.

[15] Dey, S. K.; Mandal, B.; Bhowmik, M.; Ghosh, L. K. Development and in vitro evaluation of Letrozole loaded biodegradable nanoparticles for breast cancer therapy. Braz. J. Pharm. Sci. 2009, 45, 585-591.

[16] Haghiralsadat, F.; Amoabediny, G.; Naderinezhad, S.; Helder, M. N,; Akhoundi Kharanaghi, E.; Zandieh-Doulabi, B. Overview of Preparation Methods of Polymeric and Lipid-Based (Noisome, Solid Lipid, Liposome) Nanoparticles: A Comprehensive Review. Int. J. Polym. Mater. 2017, 67, 383-400. DOI: 10.1080/00914037.2017.1332623.

[17] Moghaddam, F. D.; Akbarzadeh, I.; Marzbankia, E.; Farid, M.; Reihani, A. H.; Javidfar, M.; Mortazavi, P. Delivery of melittin-loaded niosomes for breast cancer treatment: an in vitro and in vivo evaluation of anti-cancer effect. Cancer Nano. 2021, 12, 1-35. DOI: 10.21203/rs.3.rs-136057/v1.

[18] Moghtaderi, M.; Mirzaie, A.; Zabet, N.; Moammeri, A.; Mansoori-Kermani, A.; Akbarzadeh, I.; Eshrati Yeganeh, F.; Chitgarzadeh, A.; Bagheri Kashtali, A.; Ren, Q. Enhanced Antibacterial Activity of Echinacea angustifolia Extract against Multidrug-Resistant Klebsiella pneumoniae through Niosome Encapsulation. Nanomaterials (Basel). 2021, 11, 1573. DOI: 10.3390/nano11061573.

[19] Agarwal, S.; Mohamed, M. S.; Raveendran, S.; Rochani, A. K.; Maekawa, T.; Kumar, D. Formulation, characterization and evaluation of morusin loaded niosomes for potentiation of anticancer therapy. RSC adv. 2018, 8, 32621-32636. DOI: 10.1039/C8RA06362A.

[20] Ghafelehbashi, R.; Akbarzadeh, I.; Yaraki, M. T.; Lajevardi, A.; Fatemizadeh, M.; Saremi, L. H. Preparation, physicochemical properties, in vitro evaluation and release behavior of cephalexin-loaded niosomes. Int. J. Pharm. 2019, 569, 118580. DOI: 10.1016/j.ijpharm.2019.118580.

[21] Nasseri, B. Effect of cholesterol and temperature on the elastic properties of niosomal membranes. Int. J. Pharm. 2005, 300, 95-101. DOI: 10.1016/j.ijpharm.2005.05.009.

[22] Bnyan, R.; Khan, I.; Ehtezazi, T.; Saleem, I.; Gordon, S.; O'Neill, F.; Roberts, M. Surfactant effects on lipid-based vesicles properties. J. Pharm. Sci. 2018, 107, 12371246. DOI: 10.1016/j.xphs.2018.01.005. 
[23] Chmiel, T.; Mieszkowska, A.; Kempińska-Kupczyk, D.; Kot-Wasik, A.; Namieśnik, J.; Mazerska, Z. The impact of lipophilicity on environmental processes, drug delivery and bioavailability of food components. Microchem. J. 2019, 146, 393406. DOI: 10.1016/j.microc.2019.01.030.

[24] Kumar, G. P.; Rajeshwarrao, P. Nonionic surfactant vesicular systems for effective drug delivery-an overview. Acta Pharm. Sin. B. 2011, 1, 208-219. DOI: 10.1016/j.apsb.2011.09.002.

[25] Nowroozi, F.; Almasi, A.; Javidi, J.; Haeri, A.; Dadashzadeh, S. Effect of surfactant type, cholesterol content and various downsizing methods on the particle size of niosomes. Iranian J. Pharm. Res. 2018, 17, 1-11. PMCID: PMC6447874.

[26] Moghassemi, S.; Hadjizadeh, A.; Omidfar, K. Formulation and characterization of bovine serum albumin-loaded niosome. AAPS PharmSciTech. 2017, 18, 27-33. DOI: 10.1208/s12249-016-0487-1.

[27] Gurrapu, A.; Jukanti, R.; Bobbala, S. R.; Kanuganti, S.; Jeevana, J. B. Improved oral delivery of valsartan from maltodextrin based proniosome powders. Adv. Powder Technol. 2012, 23, 583-590. DOI: 10.1016/j.apt.2011.06.005.

[28] Agarwal, R.; Katare, O.; Vyas, S. Preparation and in vitro evaluation of liposomal/niosomal delivery systems for antipsoriatic drug dithranol. Int. J.Pharm. 2001, 228, 43-52. DOI: 10.1016/s0378-5173(01)00810-9.

[29] Sadeghi, S.; Bakhshandeh, H.; Cohan, R. A.; Peirovi, A.; Ehsani, P.; Norouzian, D. Synergistic anti-staphylococcal activity of niosomal recombinant lysostaphin-LL-37. Int. J. Nanomedicine. 2019, 14, 9777. DOI: 10.2147/IJN.S230269.

[30] Barani, M.; Mirzaei, M.; Torkzadeh-Mahani, M.; Nematollahi, M. H. Lawsoneloaded Niosome and its antitumor activity in MCF-7 breast Cancer cell line: a Nanoherbal treatment for Cancer. DARU J. Pharm. Sci. 2018, 26, 11-17. DOI: 10.1007/s40199-018-0207-3.

[31] Moghassemi, S.; Parnian, E.; Hakamivala, A.; Darzianiazizi, M.; Vardanjani, M. M.; Kashanian, S.; Larijani, B.; Omidfar, K. Uptake and transport of insulin across intestinal membrane model using trimethyl chitosan coated insulin niosomes. Mater. Sci. Eng. C. Mater. Biol. Appl. 2015, 46, 333-340. DOI: 10.1016/j.msec.2014.10.070.

[32] Waddad, A. Y.; Abbad, S.; Yu, F.; Munyendo, W. L.; Wang, J.; Lv, H.; Zhou, J. Formulation, characterization and pharmacokinetics of Morin hydrate niosomes prepared from various non-ionic surfactants. Int. J. Pharm. 2013, 456, 446-458. DOI: 10.1016/j.ijpharm.2013.08.040

[33] Malatesta, M.; Giagnacovo, M.; Costanzo, M.; Conti, B.; Genta, I.; Dorati, R.; Galimberti, V.; Biggiogera, M.; Zancanaro, C. Diaminobenzidine photoconversion is a suitable tool for tracking the intracellular location of fluorescently labelled nanoparticles at transmission electron microscopy. Eur. J. Histochem. 2012, 16, 56, e20. DOI: 10.4081/ejh.2012.20.

[34] Chiani, M.; Azadmanesh, K.; Shokrgozar, M. A.; Mehrabi, M. R.; Akbarzadeh, A.; Norouzian, D. Enhanced antitumor effect of targeted nanoliposomal bleomycin. Chem. Biol. Drug. Des. 2017, 90, 953-961. DOI: 10.1111/cbdd.13021.

[35] Sadeghi, S.; Ehsani, P.; Cohan, R. A.; Sardari, S.; Akbarzadeh, I.; Bakhshandeh, H.; Norouzian, D. Design and Physicochemical Characterization of Lysozyme Loaded Niosomal Formulations as a New Controlled Delivery System. Pharm. Chem. J. 2020, 1-10. DOI: 10.1007/s11094-020-02100-6.

[36] Tavano, L.; Muzzalupo, R.; Picci, N.; de Cindio, B. Co-encapsulation of antioxidants into niosomal carriers: gastrointestinal release studies for nutraceutical applications. Colloids Surf. B. Biointerfaces. 2014, 114, 82-88. DOI:

10.1016/j.colsurfb.2013.09.058. 
[37] Pardakhty, A.; Varshosaz, J.; Rouholamini, A. In vitro study of polyoxyethylene alkyl ether niosomes for delivery of insulin. Int. J. Pharm. 2007, 328, 130-141. DOI: 10.1016/j.ijpharm.2006.08.002.

[38] Khazaeli, P.; Pardakhty, A.; Shoorabi, H. Caffeine-loaded niosomes: characterization and in vitro release studies. Drug Deliv. 2007, 14, 447-452. DOI: 10.1080/10717540701603597.

[39] Heidari, F.; Akbarzadeh, I.; Nourouzian, D.; Mirzaie, A.; Bakhshandeh, H. Optimization and characterization of tannic acid loaded niosomes for enhanced antibacterial and anti-biofilm activities. Adv. Powder Technol. 2020. DOI: 10.1016/j.apt.2020.11.008.

[40] Dash, S.; Murthy, P. N.; Nath, L.; Chowdhury, P. Kinetic modeling on drug release from controlled drug delivery systems. Acta Pol. Pharm. 2010, 67 (3), 217-223. PMID: 20524422.

[41] Bruschi, M. L. Strategies to modify the drug release from pharmaceutical systems. Bruschi, M. Woodhead Publishing. 2015.

[42] Korsmeyer, R. W.; Gurny, R.; Doelker, E.; Buri, P.; Peppas, N. A. Mechanisms of solute release from porous hydrophilic polymers. Int. J. Pharmaceutics. 1983, 15, 2535. DOI: 10.1016/0378-5173(83)90064-9.

[43] Balasubramaniam, A.; Anil Kumar, V.; Sadasivan Pillai, K. Formulation and in vivo evaluation of niosome-encapsulated daunorubicin hydrochloride. Drug Dev.Ind.

Pharm. 2002, 28, 1181-1193. DOI: 10.1081/ddc-120015351.

[44] Hedayati Ch, M.; Abolhassani Targhi, A.; Shamsi, F.; Heidari, F.; Salehi Moghadam, Z.; Mirzaie, A.; Behdad, R.; Moghtaderi, M.; Akbarzadeh, I. Niosomeencapsulated tobramycin reduced antibiotic resistance and enhanced antibacterial activity against multidrug-resistant clinical strains of Pseudomonas aeruginosa. $J$. Biomed. Mater. Res. A. 2021, 109 (6), 966-980. DOI:10.1002/jbm.a.37086.

[45] Lawrence, M.; Chauhan, S.; Lawrence, S.; Barlow, D. The formation, characterization and stability of non-ionic surfactant vesicles. STP pharma sciences. 1996, 6, 49-60. Corpus ID: 100565622.

[46] Seras, M.; Ollivon, M.; Edwards, K.; Lesieur, S. Reconstitution of non-ionic monoalkyl amphiphile-cholesterol vesicles by dilution of lipids-octylglucoside mixed micelles. Chem. Phys. Lipids. 1993, 66, 93-109. DOI: 10.1016/0009-3084(93)900352.

[47] Pardakhty, A.; Moazeni, E.; Varshosaz, J.; Hajhashemi, V.; Najafabadi, A. R. Pharmacokinetic study of niosome-loaded insulin in diabetic rats. DARU J. Pharm. Sci. 2011, 19 (6), 404. PMID: 23008685.

[48] Mirzaie, A.; Peirovi, N.; Akbarzadeh, I.; Moghtaderi, M.; Heidari, F.; Yeganeh, F. E.; Noorbazargan, H.; Mirzazadeh, S.; Bakhtiari, R. Preparation and optimization of ciprofloxacin encapsulated niosomes: A new approach for enhanced antibacterial activity, biofilm inhibition and reduced antibiotic resistance in ciprofloxacin-resistant methicillin-resistance Staphylococcus aureus. Bioorg. Chem. 2020, 103, 104231. DOI: $10.1016 /$ j.bioorg.2020.104231.

[49] Wood, W. G.; Igbavboa, U.; Muller, W. E.; Eckert, G. P. Statins, Bcl-2, and apoptosis: cell death or cell protection? Mol. Neurobiol. 2013, 48, 308-314. DOI: 10.1007/s 12035-013-8496-5.

[50] Yoon, O.; Roh, J. Downregulation of KLF4 and the Bcl-2/Bax ratio in advanced epithelial ovarian cancer. Onco. Lett. 2012, 4, 1033-1036. DOI: 10.3892/ol.2012.834.

[51] Hemann, M. T.; Lowe, S. W. The p53-Bcl-2 connection. Cell Death Differ. 2006, 13, 1256-1259. DOI: 10.1038/sj.cdd.4401962. 
[52] Vaseva, A. V.; Moll, U. M. The mitochondrial p53 pathway. Biochim. Biophys. Acta. 2009, 1787, 414-420. DOI: 10.1016/j.bbabio.2008.10.005.

[53] Vousden, K. H.; Lu, X. Live or let die: the cell's response to p53. Nat. Rev. Cancer. 2002, 2 (8), 594-604. DOI: 10.1038/nrc864.

[54] Costanzo, M.; Carton, F.; Marengo, A.; Berlier, G.; Stella, B.; Arpicco, S.; Malatesta, M. Fluorescence and electron microscopy to visualize the intracellular fate of nanoparticles for drug delivery. Eur. J. Histochem. 2016, 60, 2640. DOI: 10.4081/ejh.2016.2640.

[55] Varkouhi, A. K.; Scholte, M.; Storm, G.; Haisma, H. J. Endosomal escape pathways for delivery of biologicals. J. Control. Release. 2011, 151, 220-228. DOI: 10.1016/j.jconrel.2010.11.004.

[56] Xia, X.-X.; Wang, M.; Lin, Y.; Xu, Q.; Kaplan, D. L. Hydrophobic drug-triggered self-assembly of nanoparticles from silk-elastin-like protein polymers for drug delivery. Biomacromolecules. 2014, 15, 908-914. DOI: 10.1021/bm4017594.

[57] Amiri, B.; Ebrahimi-Far, M.; Saffari, Z.; Akbarzadeh, A.; Soleimani, E.; Chiani, M. Preparation, characterization and cytotoxicity of silibinin-containing nanoniosomes in T47D human breast carcinoma cells. Asian Pac. J. Cancer Prev. 2016, 17, 3835-3838. PMID: 27644625.

[58] Kanaani, L.; Javadi, I.; Ebrahimifar, M.; Ebrahimi Shahmabadi, H.; Akbarzadeh Khiyavi, A.; Mehrdiba, T. Effects of cisplatin-loaded niosomal nanoparticleson BT-20 human breast carcinoma cells. Asian Pac. J. Cancer Prev. 2017, 18 (2), 365. DOI: 10.22034/APJCP.2017.18.2.365.

[59] Amiri, B.; Ahmadvand, H.; Farhadi, A.; Najmafshar, A.; Chiani, M.; Norouzian, D. Delivery of vinblastine-containing niosomes results in potent in vitro/in vivo cytotoxicity on tumor cells. Drug Dev.Ind. Pharm. 2018, 44, 1371-1376. DOI: 10.1080/03639045.2018.1451880. 


\section{Supplementary Files}

This is a list of supplementary files associated with this preprint. Click to download.

- letrozolegraphical.jpg 